\title{
Taxonomy
}

\section{Three rare European “Alona” taxa (Branchiopoda: Cladocera: Chydoridae), with notes on distribution and taxonomy}

\author{
Kay Van Damme ${ }^{1}$, Manuel Elías-Gutiérrez ${ }^{2}$ and Henri J. Dumont ${ }^{1}$ \\ 1 Department of Biology, Ghent University, K.L. Ledeganckstr 35, B-9000 Ghent, Belgium \\ 2 El Colegio de la Frontera Sur, Av. Centenario Km 5.5, Chetumal 77014, Quintana Roo, México
}

Received 28 September 2009; Accepted 10 September 2010

\begin{abstract}
Taxonomical efforts in freshwater zooplankton are continuously needed for the delineation of species. Even today, confusion exists in correct identification of several European Cladocera because of poor original descriptions and subtle differences in morphology. In this context, we discuss three of the rarest Alona-like Chydoridae in the Palaearctic and their validity. 1) Alona moniezi, only reported once from Vichy area, France, has a male indistinguishable from that of $A$. elegans Kurz, 1875 while females show characters of $A$. elegans and of Coronatella rectangula. We provide a description of this taxon, with intermediate morphology and discuss the possibilities of hybridization. 2) Alona karelica is unusual as one of the few eurythermic species of a predominantly stenothermic A. pulchella-group. We discuss Neotropical A. cf. karelica from Mexico as its closest relative. Both show similarities with the semi-terrestrial $A$. bromelicola from Nicaragua, forming a small $A$. karelica-section within the $A$. pulchella-group. 3) A. weltneri is redescribed based on type material and we confirm it as a member of the $A$. costata-group. We discuss the three taxa and expand their diagnosis. A. weltneri and A. karelica are both found sporadically, and little is known about their ecology. Their scarcity in the Palaearctic may be linked with specialisation to a peculiar habitat and the possibility that these are true relicts.
\end{abstract}

Key words: Alona karelica / Alona weltneri / Alona moniezi (Alona elegans group) / Chydoridae / Cladocera / Palaearctic

\section{Introduction}

Continuous efforts in cladoceran taxonomy are vital for our basic understanding biogeography, ecology, biodiversity and evolution of the group (Dodson and Frey, 1991). Molecular methods now reveal wide cryptic diversities, yet obscure taxa with poor original descriptions remain forgotten, leading to a never ending confusion. Even in Europe, such "pseudo-cryptic" species still exist, taxa with valid names that are not considered part of the existing diversity. The largest family of Cladocera, the Chydoridae, deserves continuation of efforts in taxonomy, to allow further studies that rely on basic species delineation. In this context, we contribute here by adding to the knowledge on three forgotten European chydorid taxa. The Chydoridae are phytophilic-benthic microcrustaceans (Branchiopoda: Cladocera) that make up a significant proportion of the invertebrate biomass in the littoral of freshwaters worldwide (Smirnov, 1971).

Corresponding author: Kay.Vandamme@ugent. be
In the Chydorinae, few experts are able to distinguish the European species in Chydorus Leach, 1816, such as C. ovalis Kurz, 1875 and C. latus Sars, 1862, from C. sphaericus (O.F. Müller, 1776). These species, recognized by several authors a century ago, are actually very different in morphology (see drawings in Flößner, 2000; Hudec, 2010). At the same time, cryptic species in the European C. sphaericus-complex were unraveled by molecular methods (Belyaeva and Taylor, 2009), but unaccompanied with detailed morphological revision of the parthenogenetic females (e.g., limb morphologies). Therefore, continuous efforts in revision and sorting out available names to check if newly found cryptic species may have existing names, are necessary.

Within the largest subfamily, the Aloninae, the bulk of the species are classified - by tradition - in Alona Baird, 1843. The genus Alona is confusing, comprising different cryptic genera with externally similar appearance. An ancient tradition of lumping in Alona has resulted in a most complex situation. Recently, a major split in Alona was suggested with separation of the Alona rectangulagroup into Coronatella (Van Damme and Dumont, 
2008b); the Alona monacantha-group was also shifted to latter genus (Van Damme et al., 2010), but the "A." elegans-group remains lumped, pending revision. For a checklist of all available taxa in Alona, their current position and a list of all newly derived genera, see Van Damme et al. (2010); a history of the genus and redescription of the type can be found in Van Damme and Dumont (2008a).

Alona contains species groups with wide distribution in the Palaearctic. A. affinis (Leydig, 1860), A. costata Sars, 1862, A. guttata Sars, 1862, A. quadrangularis (O.F. Müller, 1776), and Coronatella rectangula (Sars, 1861) (former $A$. rectangula Sars, 1861) for example, are common, widespread, and build significant populations. A. rustica Scott, 1895 and A. intermedia Sars, 1862 are less commonly found in Western Europe, but where they occur, these species may reach considerable abundances. A few taxa, with peculiar morphology, are restricted to parts of the Mediterranean basin (A. azorica Frenzel and Alonso, 1988, A. orellanai Alonso, 1886, A. nuragica Margaritora, 1971 and A. salina Alonso, 1996) (e.g., Alonso, 1996).

Two members of Alona are extremely rare. These have mainly been reported from the Palaearctic, each time represented by few specimens only: Alona karelica Stenroos, 1897 and $A$. weltneri Keilhack, 1905. We investigate their morphology and status in an attempt to refine their taxonomic affinities. A. weltneri is suggested as a member of the A. costata-group (Flößner, 2000; Sinev, 2008) because of the typical slit-like lateral pores, but its finer morphology and trunk limb features remained unknown. We redescribe $A$. weltneri from Keilhack's holotype. Similarly, of A. karelica, a member of the A. pulchella-complex, limb morphology had remained a mystery (e.g., Sinev, 2002a). Records of A. cf. karelica exist from outside the Palaearctic, from Neotropics and even East Asia (e.g., Idris and Fernando, 1981; Rey and Vásquez, 1986; Elías-Gutiérrez et al., 2008). We included specimens from Mexico (coll. by the Mexican Institute for Oil, IMP and work done by Dimas-Flores, 2002) in a preliminary comparison with European material. Comparative A. karelica specimens from Slovakia provided by Dr I. Hudec, allowed a partial description of its limb morphology (see also Hudec, 2010). Finally, we redescribe a third taxon, Alona moniezi Richard, 1888, of which type material was found adequately preserved at the Smithsonian (see Kotov and Ferrari, 2010). Of A. moniezi only the original description, without illustrations, exists (Richard, 1888; Kotov and Ferrari, 2010); it is presented and depicted for the first time here. The animal, found near Vichy, Allier Department, France, by Richard (1888), was regarded as incertae sedis or a form of $A$. rectangula (Smirnov, 1971: 486). We discuss the morphology of this taxon based on the types and similarities with A. elegans Kurz, 1875. We conclude with a discussion of factors that may lie at the base of the apparent scarcity of these Chydoridae in the Palaearctic. This study is also part of a wider revision of the lump genus Alona Baird, 1843 in continuation of work by A.Y. Sinev and of works by Van Damme and Dumont (2008a, 2008b) and Van Damme et al. (2009, 2010).

\section{Systematic part}

Family Chydoridae Dybowski and Grochowski, 1894 emend. Frey, 1967.

Subfamily Aloninae Dybowski and Grochowski, 1894 emend. Frey, 1967.

\section{Alona karelica Stenroos, 1897 (Alona pulchella group)}

A. karelica in Stenroos (1897: 52-53, Figs. 5-6); Herbst (1962: 88, Fig. 66); Herbst (1974: 136, Figs. 6-10); Hudec (2010: 330-332, Figs. 81A-81O); Smirnov (1971: 474-475, Figs. 464 and 465.1); Flößner (2000); A. rectangula karelica in Weigold (1911).

Non A. cf. karelica in Idris and Fernando (1981).

Non A. karelica in Rey and Vásquez (1986).

Non $A$. prope karelica in Maiphae et al. (2005).

\section{Material examined}

A. karelica-One parthenogenetic female in slide, dissected, between Zatín and Bol' (Trebisov, Kosice), Slovakia, 22.IX.1981, swamp near road, coll. by Dr I. Hudec (Hudec, 1986). Kept at Ghent University, Ghent, Belgium.

\section{Redescription of adult parthenogenetic female}

Habitus (Figs. 1A-1B). Medium-sized animals, $0.4 \mathrm{~mm}$ $(-0.5 \mathrm{~mm}$ in Flößner, 2000), yellowish transparent. In lateral view carapace oval-rectangular with moderately arched dorsal margin and low posterodorsal angle (Figs. 1A-1B). Ventral carapace margin straight to convex in middle (Figs. 1A-1B). Posteroventral corner broadly round, without notch. Dorsal keel absent. Head. Eye diameter 1.6 times as large as that of ocellus (Fig. 1A). Head shield in Hudec (2010: Tab. 81E) with posterior part (beyond mandibular articulation) shorter than anterior part; posterior part twice as wide as long and relatively evenly convex (not to a point). Rostrum broad and blunt, aesthetascs projecting half their length beyond its tip (Fig. 1C). Three main head pores (Fig. 1D) of same size, narrowly connected; small pores at about three IP distance from midline. Carapace (Figs. 1A-1B). Ornamentation absent or with faint points which may organize into lines (Flößner, 2000). Posterior margin convex. Marginal setae in three groups, middle group shortest. Setules in posteroventral margin separate and continuous (typical for A. pulchella complex), not arranged in clusters (see Hudec, 2010: Tab. 81, A2). Labrum (Figs. 1E-1F). Labral keel in lateral view round, about as wide as high, with moderately convex margin and obtuse tip with indentation 


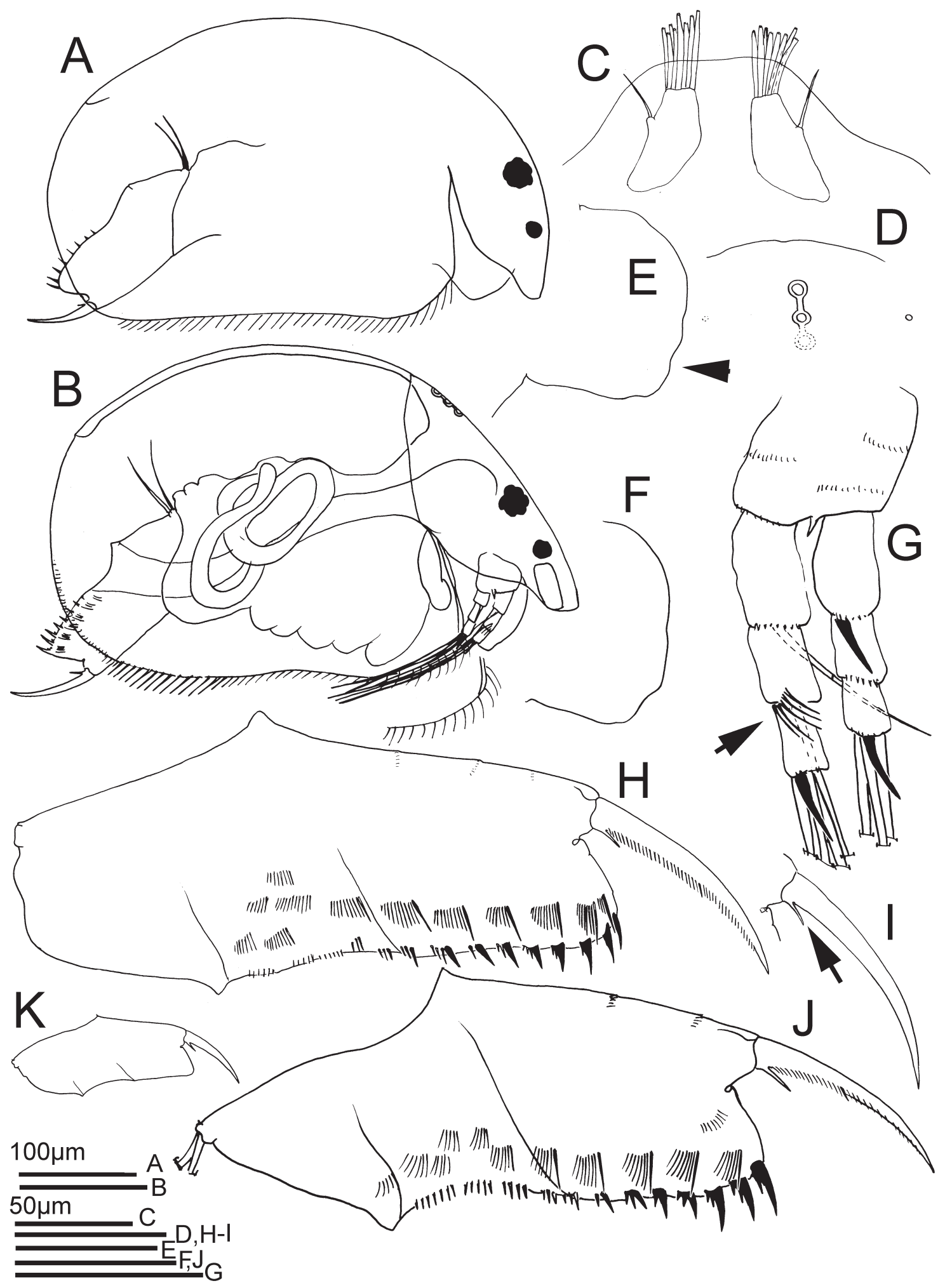

Fig. 1. Alona karelica Stenroos, 1897 from Trebisov, Kosice, Slovakia, Coll. Dr I. Hudec (A, C, E, D, G-I, K) and A. cf. karelica from Jicaro, Rio Coatzacoalcos (Veracruz) Mexico, Coll. IMP, Det. Noemí Dimas-Flores and Manuel Elías-Gutiérrez (B, F, J). A: Habitus (from Flößner, 2000); B: Habitus Mexican A. cf. karelica; C: Rostrum and antennules; D: Head pores; E: Labral keel European A. karelica; F: Idem, Mexican A. cf. karelica; G: Second antenna; H: Postabdomen; I: Idem, terminal claw; J: Idem, Mexican A. cf. karelica; K: general shape of postabdomen. 
(Figs. 1E-1F). Labral keel margin not straight, may appear wavy in ventral part (Fig. 1E, arrow). No ventral setules or denticles on labral keel. Antennules (Fig. 1C). About two times as long as wide, sensory seta implanted at between one third and half of apex and in length not reaching beyond half of aesthetasc lengths. Setules on margin of antennule not seen. Aesthetascs about half as long as antennular corm, subequal in length (two little longer). Second antennae (Fig. 1G). Basal setae not studied. Basal spine large, longer than wide (Fig. 1G). Spinal formula $001 / 101$, setal formula $113 / 003$. First exopod seta on antenna fine, reaching beyond ultimate segment (Fig. 1G); on external side of second exopod segment, group of five to six fine, curved spinules reaching half of last exopod segment (Fig. 1G, arrow). Spine on first endopod segment reaching base of third endopod segment; main terminal spines on endo- and exopod well developed and longer $(1.2 \times)$ than ultimate segment (Fig. 1G). Terminal setae subequal in length.

Postabdomen (Figs. 1H-1K). Narrow and straight in overall shape, its length two to 2.5 times its width, with protruding relatively acute dorso-distal margin. Ventral margin about as long as anal and postanal margin. Postanal margin longer $(1.3 \times)$ than anal margin. Anal margin straight to concave, postanal margin straight, relatively parallel to ventral margin. Distal margin protruding. Preanal corner well developed, triangular, protruding beyond postanal margin. Marginal denticles, merged teeth in proximal part of postanal margin, three groups closest to anal margin unmerged. In total, eight to nine postanal marginal teeth/clusters. In Europe, they may decline gradually in length towards anal margin, as in specimen studied here, or three first longer (as in Herbst, 1974). Lateral fascicles five groups in postanal portion, consisting of nine to twelve spinules in each group, parallel to each other, slightly increasing in size distally and with longer and slightly thicker distal spinule per group. Three clusters of marginal denticles and two to three rows of fascicles in anal portion. Terminal claw (Fig. 1I). Longer $(1.3 \times)$ than anal margin, relatively straight in proximal two thirds, implanted with setules along dorsal side. Short thin basal spine, as short as claw thickness at base, an important character for A. karelica. No basal spinules seen. If present, they are minute (Fig. 1I). Shape of postabdomen repeated in Figure $1 \mathrm{~K}$ (preanal convexity in margin is an artifact, this is straight; see postabdomen in Fig. 1A).

First maxilla not seen. Five pairs of limbs. First limb (Figs. 2A-2B). First endite with two marginal setae, the first seta in this endite is absent (typical for A. pulchellagroup). Second endite with three setae (one broken off), third endite with four setae (one broken off); anterior elements absent (Fig. 2A). ODL with one slender seta (Fig. 2A); IDL with three setae; armature of two largest IDL setae short unilateral setules in distal half, no strong denticles or spines. Accessory seta not seen. Six anterior setule groups with average five fine setules in each group, not decreasing in size ventrally. Ejector hooks not seen.
Second limb (Fig. 2C). Exopodite longer than wide, lacking a seta but with few minute setules; endites with eight scrapers gradually decreasing in size towards gnathobase, eight scraper shortest. First four scrapers relatively more slender and finely setulated, next four thicker and more rigid; length of scrapers gradually decreasing in size to fifth scraper and then suddenly shorter sixth to eight (sixth one third shorter of fifth). Gnathobasic "brush" short and implanted with short spinules, gnathobase with a sensillum and three modified elements, of which first a bent seta, second a plump seta with small denticles in distal half and third a simple naked seta; filter comb (Fig. 2C; fc) with eight (!) setae of which only the first two shorter (half size of second) - in Hudec (2010) only seven setae in this position. First seta indicated as "a" in Figure 2C, unusual for $A$. pulchella-group; normally only one seta shorter here instead of two.

Third limb (Figs. 2D-2E). Exopodite (Fig. 2D) with rectangular corm and seven large marginal setae in $2+5$ arrangement; first exopodite seta longer than second; third exopodite seta $1.5 \times$ as long as sixth exopodite seta, fourth and sixth setae subequal, fourth being longer (but not completely visible in slide), seventh setae half size of sixth (and longer than fifth). Sixth seta relatively long and narrow. External endite (Fig. 2G) with three setae (1'-3') of which first two a third longer than 3', latter with long setules; four well developed setae on inner side (setules not seen; 1"-4") of same length; one naked element and four slender setae on internal endite (Fig. 2F) preceding gnathobase; gnathobase (Fig. 2H) with bottle-shaped sensillum(s) and bent plumose seta with two naked elements at its base (Fig. 2H). Filter comb of this endite with seven long setae (Fig. 2H).

Fourth limb (Fig. 2I). Epipodite oval, with short projection. Exopodite square, with six marginal plumose setae, but last two (closest to endopodite) with relatively shorter setules; first seta longest, second and third setae of similar lengths; fifth and sixth setae not narrow as in majority of Aloninae but as thick as other setae; sixth and fifth setae of similar length (four longest) and between half and two thirds as long as fifth seta. Gnathobase with typical arrangement and five filter setae (not shown).

Fifth limb (Figs. 2J-2K). Exopodite (Fig. 2J) shape broadly oval, about two times as long as wide, with straight expanded margin between setae three and four; four exopodite setae, gradually decreasing in size, first (dorsal) longest, oriented dorsally, little longer than exopodite itself; fourth exopodite seta as thick as other setae and about half as long as third; inner portion of limb (Fig. 2K) with broadly oval inner lobe; two endite setae $\left(1^{\prime}-2^{\prime}\right)$ of which first slightly longer. No gnathobase elements or filter comb seen.

Sixth limb absent.

Adult male not studied here. Depicted in Flößner (2000) from Herr (1917) and original drawings in Hudec (2010). Size (according to description) $0.36 \mathrm{~mm}$, dorsum straight (not arched), with parallel ventral and dorsal margins. Postabdomen (Hudec, 2010: Tab. 81N) about 


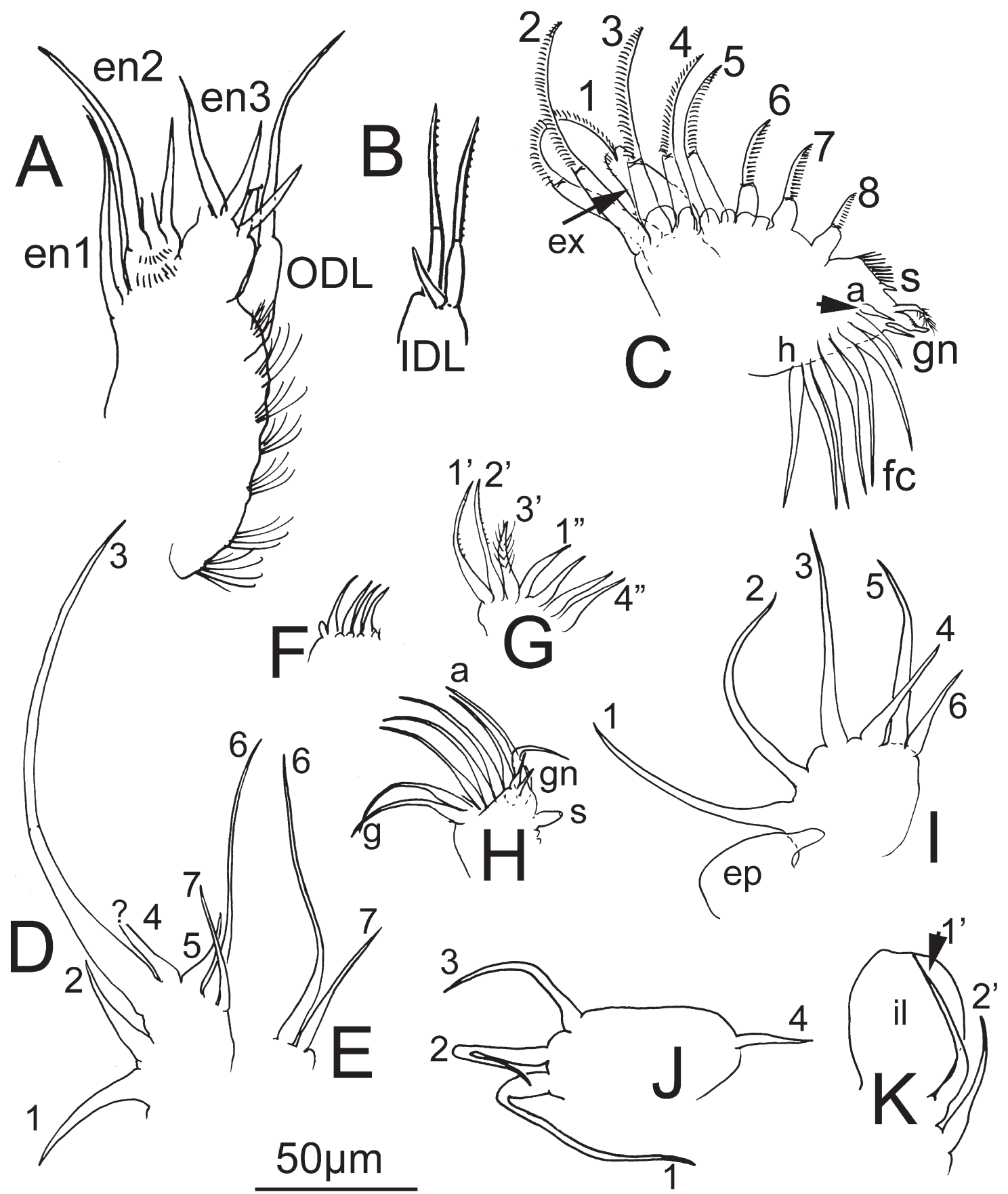

Fig. 2. Alona karelica Stenroos, 1897 from Trebisov, Kosice, Slovakia, Coll. Dr I. Hudec. Limb morphology of adult parthenogenetic female. A: First limb (no setules, and some setae not visible); B: Idem, IDL (from Flößner, 2000); C: Second limb; D: Third limb, exopodite; E: Idem, sixth and seventh setae; F: Idem, internal endite setae; G: Idem, external endite setae; H: Idem, gnathobase and filter comb; I: Fourth limb, exopodite; J: Fifth limb, exopodite; K: Fifth limb, inner portion.

Abbreviations: $\mathrm{a}-\mathrm{h}$, enumeration filter setae; en1-en3, endites one to three; ep, epipodite; fc, filter comb; gn, gnathobase; IDL, inner distal lobe; il, inner lobe; ODL, outer distal lobe; s, sensillum.

2.5 times as long as wide, with straight dorsal and ventral margins, lacking the protruding dorsodistal angle. Instead, postabdomen almost rectangular with basal claws on a projection in the middle. Gonopores open ventrally to the basal claws. Basal spine on claw is minute, less than width of claw at base. Marginal denticles in male postabdomen exist of separate clusters. Copulatory hook U-shaped, with blunt apex and two to three small ridges, distal longer than proximal half of the hook (see Hudec, 2010: Tab. 81O).

\section{Differential diagnosis}

Alona karelica displays all characters of the Alona pulchella-complex, a large assemblage of over fifteen 
species worldwide. Typical for this group is a straight and elongate postabdomen, with relatively acute dorsodistal margin and parallel ventral and dorsal margins. In Europe, no other Alona-like taxon has a similar (straight, parallel) postabdomen, not counting the occurrence in the Mediterranean of A. cambouei, in Turkey (Yalim and Ciplak, 2005) and Spain (Van Damme, pers. obs.). The postabdomen in A. guttata, A. rustica and A. costata may seem remotely similar to that in the $A$. pulchella-group, but in the latter, the postabdomen is more elongated and sawlike; none of these common European species has the short basal spine, present in A. karelica. In the Netherlands, confusion with $A$. guttata has lead to erroneous inclusion of the species in the country's cladoceran checklist (Soesbergen and van de Sande, 2009). A rare character for A. karelica within the A. pulchella-complex is the long terminal claw on the postabdomen (longer than anal margin) and this very short basal spine (shorter than claw width at base), only shared with $A$. bromelicola from Nicaragua. The latter species is different in having reduced aesthetascs on its first antenna and shorter spines on its second antenna than $A$. karelica. The two are, however, similar. In A. karelica, the group of spinules on the second exopod segment of the antenna is long (up to half third segment; arrow in Fig. 1G) in comparison to all other species of the $A$. pulchella-complex; the endopod spine on the first segment reaches the basis of the third segment (Fig. 1G). A conspicuous character for A. karelica is an indentation of the labral keel, also present in the male (cf. drawings in Herr, 1917). This occurs in several species of the A. pulchella complex as well (e.g. A. glabra, A. pulchella, A. cambouei). The limbs are typical for the A. pulchella-group, but the sixth seta of the $\mathrm{P} 3$-exopodite is relatively long. The eighth seta in the filter comb of P2 is aberrant for this specimen - Hudec (2010) depicts seven setae here.

\section{Distribution and biology}

Alona karelica as redefined above, is only known from the Palaearctic. It is the only member of the A. pulchellacomplex in Europe that occurs outside the Mediterranean. Originally described from Karelia (Stenroos, 1897), it has invariably been found sporadically and in low numbers (one-three specimens). A. karelica is on record from Slovakia, Austria, Poland, Estland, Finland, Norway, Siberia (Smirnov, 1971), Denmark (Sinev, 2002b) and following records. The largest number of localities is situated in Germany e.g., Lakes Stechlin, Boberow, Oberlausitz (Saxony) the Bienener Altrhein (Old Rhine) (Herbst, 1974; Flößner 1962, 2000) and Hammerlug (between Neudorf and Creba) (Herr, 1917). Margins of Volga Water Reservoirs in Russia (Smirnov, 1963). South Finland and Siberia, Jamal Peninsula (Smirnov, 1971), in Hungary (River Bodrog) and East Slovakia (Stážne, Velke Kapušany, river Latorica, Leles; Hudec, 1980, 1986, 2010). Records from Austria (Steiermark, Graz) are unclear (Flößner, 2000). Earlier records from The Netherlands are misidentifications (Soesbergen and van de Sande, 2009).
Records from South-East Asia listed as A. cf. karelica (in Idris and Fernando, 1981; Maiphae et al., 2005) are rejected, as the basal spine of the postabdomen is too long for this species; these records most likely correspond to $A$. archeri Sars, 1888. A sibling of $A$. karelica may be expected in the Nearctic, where three more members of the A. pulchella-complex occur (A. lapidicola Chengalath and Hann, 1981, A. borealis Chengalath and Hann, 1981 and A. setulosa Megard, 1967; all three, although aberrant postabdomen morphology, are regarded as members of pulchella-complex; Van Damme et al., 2010). Ecology of A. karelica is poorly known. In the Palaearctic, the species is considered eurythermic, found in dense vegetation of weakly acidic waters $(\mathrm{pH}>5.0)$ (Flößner, 2000). An association with Sphagnum together with A. rustica (e.g., Flößner, 2000) was recently confirmed in a dystrophic lake from Drawno or Drawieński National Park, W-Pomerania (Poland) by Kuczyńska-Kippen (2008). In swamps, marshes or old river oxbows and shallow water (e.g., Herr, 1917; Hudec, 1986, 2010), on muddy bottom with plant remains, among roots in Hydrochariton, at water temperatures up to $27.2^{\circ} \mathrm{C}$ (Hudec, 1986) and together with $C$. sphaericus and $O$. tenuicaudis (Hudec, 2010). According to Thienemann (1950) and Herbst (1974) A. karelica is an "Ice Age relic" (see below). Records in literature range from May to September.

\section{Alona cf. karelica Stenroos, 1897 (Alona pulchella group)}

A. karelica in Rey and Vásquez (1986: 156, Plate 9, Figs. 1-11); A. cf. karelica in Dimas-Flores (2002: 85-87, Figs. IVA-IVG); $A$. cf. karelica in Elías-Gutiérrez et al. (2008: 115, 119, Figs. 43.6-43.7).

\section{Material examined}

A. cf. karelica-Three parthenogenetic females from two localities located in Río Coatzacoalcos, Veracruz, Mexico (San Antonio 18 $0^{\prime} 41^{\prime \prime}$ N, 94 26'52" and Jicaro 1753'29" N, 94²6'52"), 27.IX.1997, Coll. IMP, Det. Noemí Dimas Flores and Manuel Elías-Gutiérrez. Mexican material deposited at El Colegio de la Frontera Sur, Chetumal, Mexico. Accession Numbers ECO-CH-Z02670 to 02672 .

\section{Diagnosis}

Limb characters not studied. Habitus with straight dorsum (Fig. 1B) (seems more arched in A. karelica). A. cf. karelica differs in one very clear feature from $A$. karelica in having three most distal denticles on the postabdomen that are 1.5-2 times as long as the remaining marginal denticles (Fig. 1J); in A. karelica length differences between marginal denticles are more gradual and proximal denticles are never as long; basal spine relatively longer in $A$. cf. karelica, as long as or just longer than the proximal thickness of basal claw (in A. karelica, this is just shorter). 
Latter feature is clearly depicted in Rey and Vásquez (1986: Plate IX, 8-9) on populations from Venezuela, considered therefore identical to the Mexican populations under study. Labral keel indented below (Fig. 1F), more expressed in Mexican populations than in A. karelica. Additional character in Rey and Vásquez (1986: Plate IX, 3 ) is a central main pore half the diameter of adjacent two main pores, not all three of similar size as in A. karelica. Based on this (short) diagnosis, we consider these populations as not identical to European A. karelica.

\section{Distribution and biology}

A. cf. karelica is known from the (northern) Neotropics. Specimens have been mentioned from Venezuela and Mexico (Rey and Vásquez, 1986; Elías-Guttiérrez et al., 2008). In this region, confusion with $A$. bromelicola is possible. The record from Mexico is an animal that shows small differences with European A. karelica (e.g., postabdomen armature). A. karelica in Rey and Vásquez (1986) from Venezuela is closest to the Mexican specimens, with similar postabdomen armature (longer distal teeth on postanal margin and basal spine longer than in European A. karelica), which we think belong to the same taxon. These populations may represent a different species from true A. karelica. To decide this, analysis based on more abundant material and perhaps molecular data are required. Main problem is the rarity of specimens and lack of knowledge about its "true" habitat. The Mexican specimens studied here, were found in two different sections of the Coatzacoalcos river, at temperatures between 27.4 to $29.4{ }^{\circ} \mathrm{C}, \mathrm{pH}$ between 6.47 and 6.83 , and 0.1 UTM salinity. In one sample (Jícaro), A. cf. karelica was found together with Bryospilus repens Frey, 1980 (Dimas-Flores, 2002). River plankton is an unusual habitat for these two taxa. B. repens is a well known semiterrestrial species, living in wet moss. We speculate that specimens were washed into the river after rains, common during this season. Rey and Vásquez (1986) also found this animal connected to a river (Orinoco), in littoral between Paspalum repens.

\section{Alona weltneri Keilhack 1905 (Alona costata group)}

Keilhack (1905): 158-159, Figures 13-14; Keilhack (1908): 464, Figure 20; Flößner (2000): 322-323, Figure 119.

\section{Material examined}

Single adult parthenogenetic female in slide (Holotype), from Museum für Naturkunde, Berlin, $\mathrm{n}^{\circ}$ 18948, from type locality, Madü-See (= Jezioro Miedwie), Pyrzyce (Pyritz), W-Pomerania, Poland, Coll. W. Weltner, 04.VIII.1901, Det. L. Keilhack.

\section{Redescription of adult parthenogenetic female}

Habitus (Figs. 3A and 4A). Medium-sized, $0.5 \mathrm{~mm}$, straw-yellow (Keilhack, 1905). In lateral view carapace rectangular with straight to moderately arched dorsal margin (Figs. 3A and 4A). Ventral carapace margin straight, slightly concave in posterior half. Posteroventral corner broadly round, with small notch (Fig. 3L). Dorsal keel absent. Head. Eye diameter $1.4 \times$ ocellus (Fig. 3A). Head shield (Fig. 1F) narrowing posteriorly, broadly triangular in posterior part. Rostrum broad and blunt, aesthetascs projecting beyond its tip (Fig. 1A). Three main head pores (Figs. 1D-1E) of same size, narrowly connected; small pores slit-shaped with chitineous thickening, at about 1.5 IP distance from midline. No underlying sacks as in A. costata. Carapace (Figs. 3A and 4A). Ornamentation with large striation (Fig. 4A). Posterior margin concave, posteroventral corner situated more posteriorly than posterodorsal corner. Marginal setae on valve not clearly differentiated, all of similar size and decreasing in size towards posteroventral corner. Labrum (Fig. 3A). Labral keel in lateral view elongate, longer than wide, with convex margin and obtuse tip with two groups of long setules (Fig. 3K). Antennules (Fig. 3C). About two times as long as wide, sensory seta implanted at one third of apex and in length not reaching beyond half of aesthetasc lengths. Setules on margin of antennule short, in two to three rows. Aesthetascs about half as long as antennular corm, subequal in length. Second antennae not studied (broken off).

Postabdomen (Figs. 3M-3N and 4B). Narrow and straight in overall shape, length about 2.5 times width, dorsal postanal margin tapering distally. Dorso-distal margin not acute protruding as in $A$. costata, but forming a blunt straight angle. Ventral margin about as long as anal and postanal margin. Postanal margin about same length as anal margin. Anal margin straight to concave, postanal margin straight, not parallel to ventral margin but narrowing distally. Preanal corner not strongly developed, blunt, not strongly protruding beyond postanal margin. Six marginal denticles in postanal portion, all merged. Longest teeth (Fig. $3 \mathrm{~N}$ ) about 2.5 times as long as wide. Six groups of lateral fascicles in postanal portion, consisting of four to five spinules in each group, parallel among them, slightly increasing in size distally and with longer and distal spinule per group. These lateral spinules very thin and inconspicuous, and short; none reach the dorsal margin. Two clusters of marginal denticles and four groups of lateral spinules in anal portion. Terminal claw (Fig. 3M). Same length as anal margin, evenly curved and implanted with setules along dorsal side. Basal spine 1.5 times as long as basal claw thickness. Basal spinules short, not reaching half of basal spine.

Six pairs of limbs. First limb (Fig. 3G). Only IDL and ODL studied. ODL with one slender seta (Fig. 3G, left), not longer than largest IDL seta; IDL with three setae; armature of two largest IDL setae unilateral setules in distal half, no strong denticles or spines. Second limb (Fig. 3H). Exopodite with relatively short seta, not 


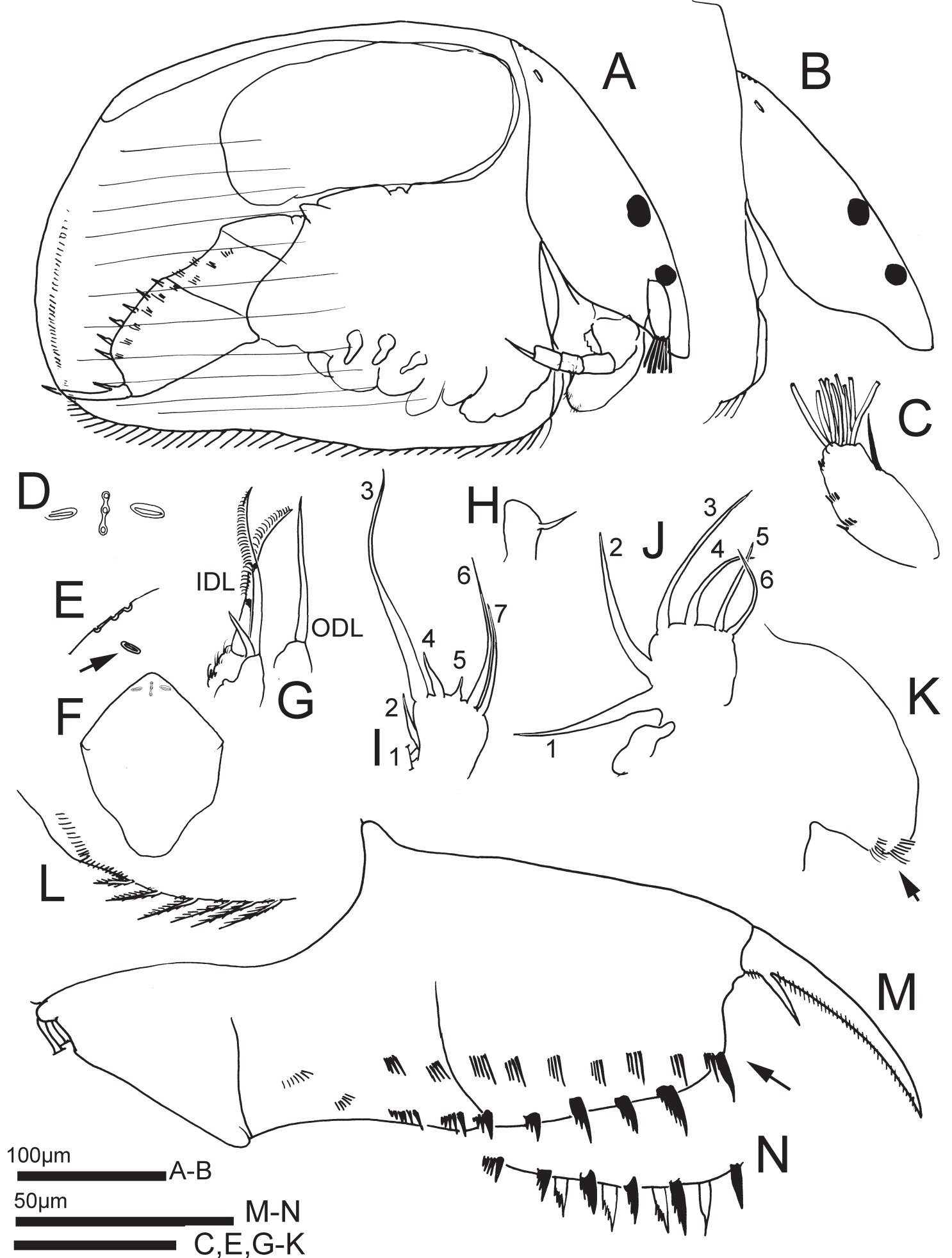

Fig. 3. Alona weltneri, Holotype from Madüsee (Jezioro Miedwie), Pomerania, Poland, Coll. W. Weltner, Det. L. Keilhack. Specimen kept at Museum für Naturkunde, Berlin. A: Habitus (reconstructed). B: Head; C: First antenna; D: Head pores (dorsal) (from Flößner, 2000); E: Head pores (dorsal) from type; F: Head shield (from Flößner, 2000); G: First limb, IDL and ODL; H: Second limb, exopodite; I: Third limb, exopodite; J: Fourth limb, exopodite; K: Labral keel; L: Posteroventral corner; M: Postabdomen; N: Idem, marginal denticles (white are from the right side of postabdomen, black left).

reaching beyond exopodite itself. Eight scrapers but detailed morphology not seen. Third limb (Fig. 3I). Exopodite (Fig. 3I) with rectangular corm and seven large marginal setae in $2+5$ arrangement; first exopodite seta incomplete; third exopodite seta 1.5 times as long as sixth exopodite seta, fourth twice as long as fifth, sixth and 

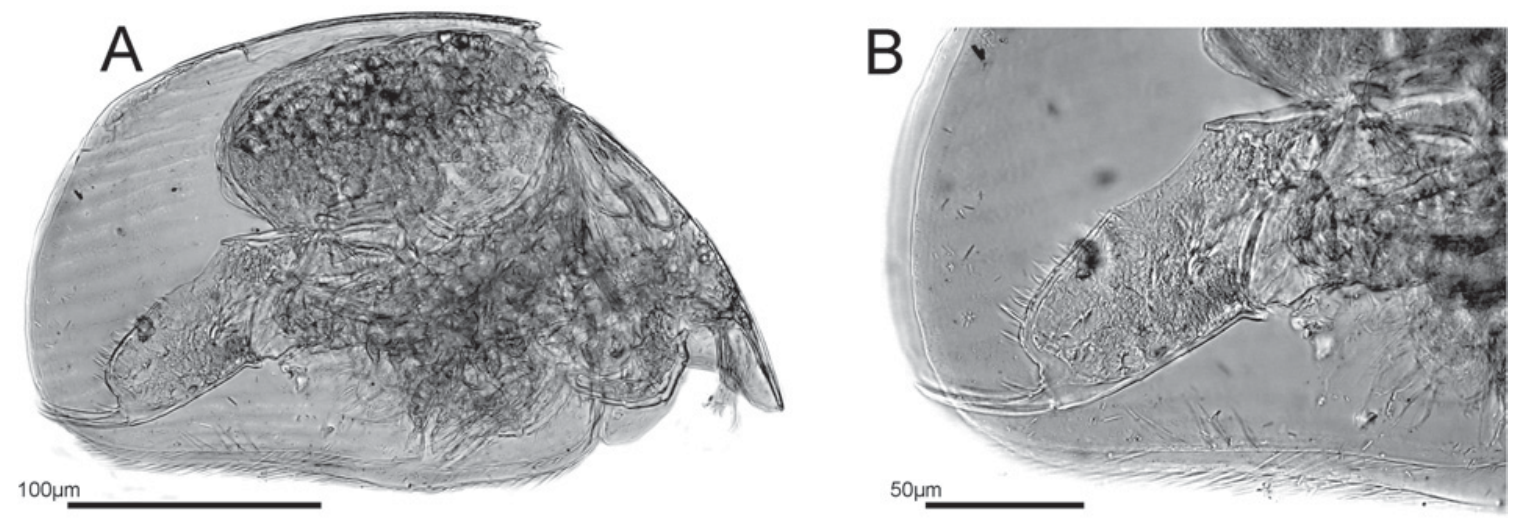

Fig. 4. Alona weltneri Keilhack, 1905, Holotype from Madusee, Poland, Det. L. Keilhack. Specimen kept at Museum für Naturkunde, Berlin. Adult parthenogenetic female. A: Habitus; B: Postabdomen and posteroventral corner of valves.

seventh setae narrow, seventh one third shorter than sixth. Fourth limb (Fig. 3J). Epipodite with short projection, not reaching half of exopodite center. Exopodite (Fig. 3J) square, with six marginal plumose setae; third seta longest, second and first setae of similar lengths; fifth and sixth setae not narrower than other setae; setae four to six all of similar lengths and one fourth shorter than third seta. Fifth limb and sixth limb not studied.

Adult male unknown. Juvenile male $(0.4 \mathrm{~mm}$ long, $0.22 \mathrm{~mm}$ high) depicted in Flößner (1962) from Lake Stechlin, Germany, shows little sexual dimorphism. Postabdomen and habitus similar in shape to female, no projection for the gonopores. This may be typical for the age of the male or a true character of $A$. weltneri.

\section{Differential diagnosis}

Alona weltneri belongs to the Alona costata-group, with which it shares the typical slit-shaped lateral pores. In the Palaearctic, Alona weltneri can only be confused with two common members of this group, A. rustica and A. costata. The latter two have a protruding distal portion of the postabdomen, giving the structure a more angular appearance. In $A$. weltneri, the dorso-distal margin is rounded, not forming a protruding angle (see Fig. 4B). In this character, it differs from all other members of the A. costata group. A. weltneri also shows few (six) postanal marginal denticles in the postabdomen; $A$. costata has more (9-12; Sinev, 1999). Another unique character for Keilhack's species is the absence of typical sacks below the lateral slits. A chitineous ring surrounds these transverse slit-shaped pores in A. weltneri. Additional features: long setules on the labral keel and the relatively long, narrow and well-spaced teeth of the postanal margin of the postabdomen. The postabdomen and labrum are also good characters to distinguish $A$. weltneri from all other Alona-like species in Europe.

\section{Distribution and biology}

Alona weltneri has been found sporadically and never in numbers. Keilhack $(1905,1908)$ found one specimen in
Lake Madü (W-Pomerania, Poland) and later two in Lake Sakrow (Germany), but never more. According to Flößner (2000), a Western Palaearctic species (Poland, Germany, Scandinavia, Switzerland). Once reported from UK (Scarborough Castle, Yorkshire; Scourfield, 1907), never found again despite intensive sampling in the UK (e.g., Fryer, 1993). One record from Holland (Soesbergen, 2002) and one from France (Rhone river interstitial; DoleOlivier, 1998), but without description or illustrations; the identifications cannot be confirmed. Nothing is known about ecological preferences, beyond the fact that it was found in the littoral of lakes (Flößner, 2000), like most Chydoridae.

\section{“Alona" moniezi Richard, 1888 (“Alona" elegans-group)}

\section{Material examined}

Twenty-one parthenogenetic females, nine males, three ephippial females, Château du Vernet, Allier, Auvergne, France, 9.V.1887, collected by J. Richard. From collection of DG Frey (DGF), Smithsonian Institution, National Museum of Natural History, Washington, US, slides labeled Alona moniezi, Richard coll. 44 and 278-280". See Kotov and Ferrari (2010) for type locality of $A$. moniezi and Richard's type material at the Smithsonian.

Additional material. Six parthenogenetic females, from underground river fed by slowly infiltrated water in a cave Cave at Balme d'Épy, Franche-Comté, Jura, France, Coll. 23.XII.2002 by A. Brancelj, PASCALIS project. Specimens now at UGent.

\section{Description of adult parthenogenetic female (type specimens)}

Habitus (Figs. 5A, 7A-7B). Medium-sized animals, $0.45-0.6 \mathrm{~mm}$. In lateral view carapace oval-round with arched dorsal margin and low posterodorsal angle (Fig. 5A). Ventral carapace margin straight (Figs. 5A-5B). Posteroventral corner broadly round, without notch. 

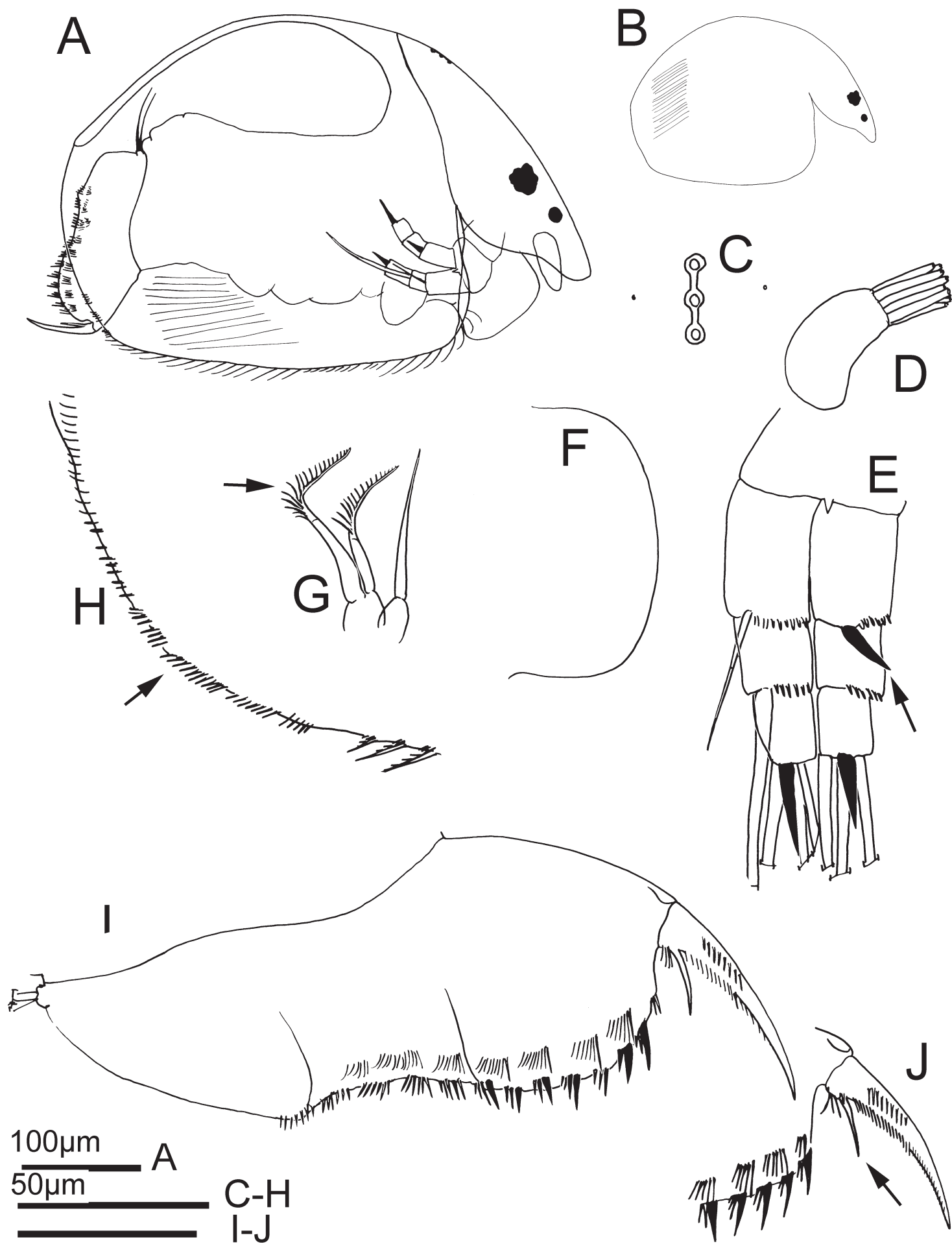

Fig. 5. Alona moniezi Richard, 1888, Allier, France, adult parthenogenetic females (= A. elegans or C. elegans $\times$ rectangula). Type material Coll. J. Richard, Château du Vernet, Allier, Auvergne, France. A: Habitus; B: Idem, outline; C: Head pores (dorsal); D: Antennule; E: Second antenna; F: Labral keel; G: First limb, IDL and ODL; H: Posteroventral corner of carapace; I: Postabdomen; J: Idem, detail terminal claw.

Dorsal keel absent. Head. Eye diameter 1.3 times that of ocellus (Fig. 5A). Head shield not studied. Rostrum broad and blunt, aesthetascs beyond it. Three main head pores (Fig. 5C) of same size, narrowly connected; small pores at about 1.5 IP distance from midline. Carapace (Figs. 5A,
7A-7B). Ornamentation with dense striation, 50-70 lines on each side (Fig. 7A). Posterior margin convex, with dorsal portion reaching more posterior than ventral half (Fig. 5A). Marginal setae in three groups, middle group shortest. Setae decreasing in size towards posteroventral 

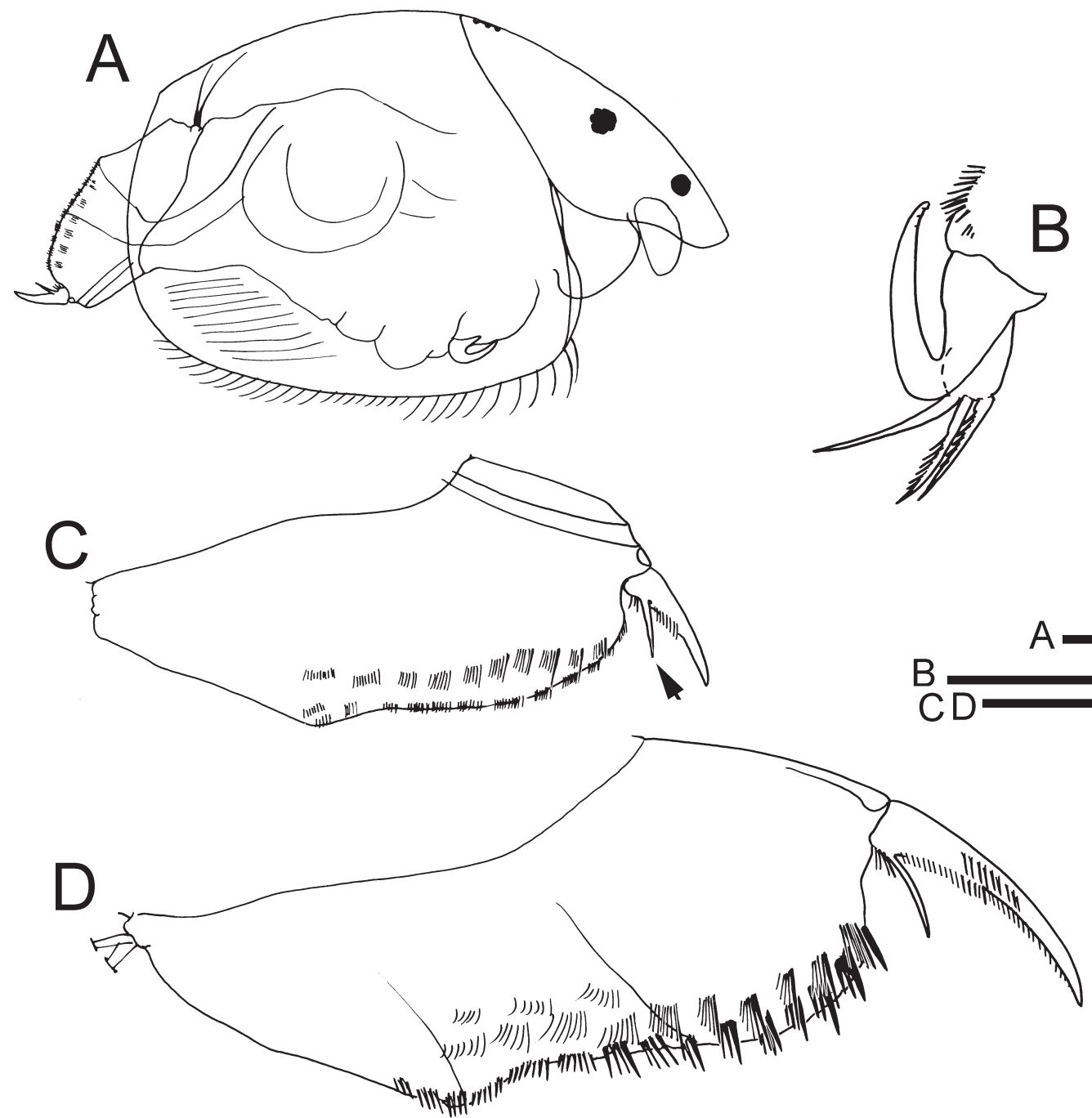

Fig. 6. Alona moniezi Richard, 1888. Type series kept at DGF. Coll. J. Richard, Château du Vernet, Allier, Auvergne, France. Adult male (= A. elegans Kurz, 1975). A: Habitus; B: First limb, copulatory hook; C: Postabdomen; D: Postabdomen adult parthenogenetic female for comparison.

corner, and beyond that, margin implanted with three to four long clusters of small denticles. Labrum (Fig. 5F). Labral keel in lateral view round, longer than wide, with moderately curved convex margin and obtuse tip. No indentations, all evenly curved. No ventral setules or denticles on labral keel. Antennules (Fig. 5D). About two times as long as wide, sensory seta and setules not seen. Aesthetascs about half as long as antennular corm, similar length. Second antennae (Fig. 5E). Basal spine short conical, as long as wide. Spinal formula 001/101, setal formula 113/003. First exopod seta on antenna fine, not reaching ultimate segment (Fig. 5E). Spine on first endopod segment shorter than or just reaching base of third segment; main terminal spines on endo- and exopod well developed and longer than ultimate segment; ultimate endopod spine $1.2 \times$ as long as segment, exopod spine 1.5 times. Terminal setae subequal in length.

Postabdomen (Figs. 5I-5J and 6D). Broad and weakly $\mathrm{S}$-shaped in dorsal margin, its length two to 2.5 times its width, and round dorso-distal margin. May be shaped as in C. rectangula, see Figure $7 \mathrm{C}$. Ventral margin shorter than anal and postanal margin. Postanal margin as long as anal margin. Preanal margin rather extensive, $1.5 \times$ as long as anal margin. Anal margin moderately concave, postanal margin convex. Distal margin not protruding. Preanal corner well developed, broadly triangular, protruding strongly beyond postanal margin. Postabdomen has a deep preanal portion. Marginal denticles unmerged groups. In total, eight to nine postanal marginal clusters, each with about three long denticles of which distal largest. Lateral fascicles four to six groups in postanal portion, consisting of nine to twelve spinules in each group, parallel to each other, increasing in size distally and with longer and slightly thicker distal spinule per group. Apex of distal spinules reaching beyond postanal margin (Fig. 6D). Four to five clusters of long marginal denticles and two rows of fascicles in anal portion. Terminal claw (Fig. 5J). Same length or just longer than anal margin, moderately curved, implanted with setules along dorsal side. Long thin basal spine, about $1.6 \times$ claw width at base and one third 


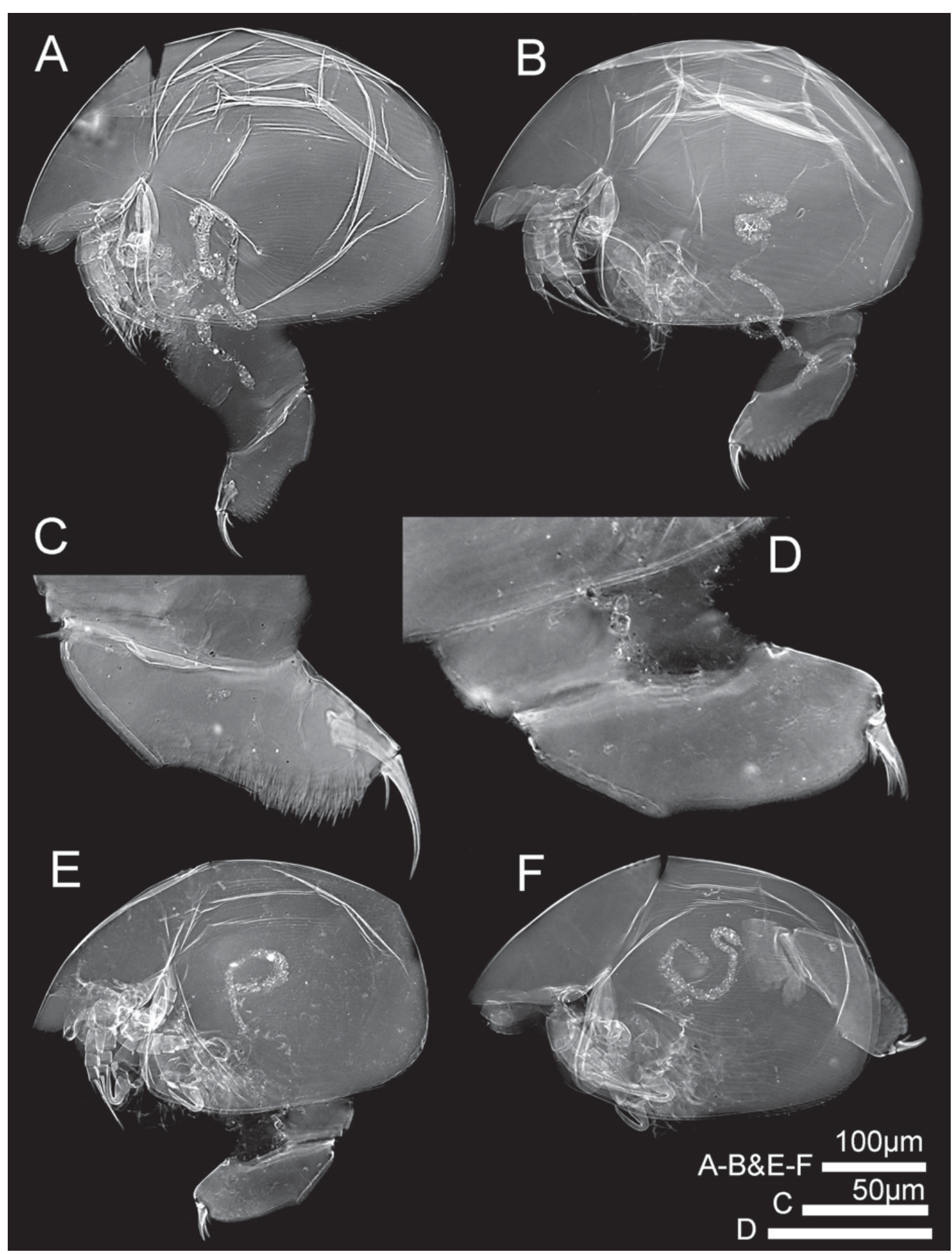

Fig. 7. Alona moniezi Richard, 1888. Type series kept at DGF (Smithsonian). Coll. by J. Richard, Château du Vernet, Allier, Auvergne, France. A: Habitus parthenogenetic female; B: Idem, ephippial female; C: female postabdomen with typical shape of rectangula, not of elegans!; D: Male postabdomen; E-F: Male habitus.

of basal claw length. Basal spinules in a group of four to six, reaching one third of basal spine length. Claw may be relatively slender (Fig. 7C).

Five pairs of limbs. First limb (Fig. 5G). Only IDL and ODL studied. ODL with one slender seta (Fig. 5G, left), not longer than largest IDL seta; IDL with two setae; armature long unilateral setules in distal half. Other limbs not seen.

Adult male. Length $0.45 \mathrm{~mm}$. Habitus (Figs. 6A and $7 \mathrm{E}-7 \mathrm{~F}$ ) similar to female, length 1.6 times width. Eye and ocellus of similar size. Marginal setae in three size 
groups, anteriormost longest (Fig. 6A). Fine striation as in females, with 45-50 lines (Figs. 6A and 7E-7F). Postabdomen (Figs. 6C and 7D) $2.2 \times$ as long as wide, with gonopores opening subapically, just near base of terminal claw. Terminal claw as long as anal margin and narrowing strongly towards apex. Basal spine reaching half of terminal claw (Fig. 6C). Anal and postanal margin of postabdomen (Figs. 6C and 7D) without difference, as one straight line. Preanal corner broad and weakly protruding, but reaching beyond postanal margin and is dorsalmost point of postabdomen (as in females). Marginal denticles in small clusters of eight to fifteen small spinules each. Five to seven such clusters in postanal portion. Lateral fascicles seven in postanal portion, distal most longest. First limb (Fig. 6B) with copulatory hook with distal part longer than proximal part and relatively narrow in distal part. IDL with three setae.

\section{Notes}

Alona moniezi falls within the Alona elegans-complex, of which variability at species level (of $A$. elegans) remains to be studied in detail. A. moniezi has a similar fine striation on the valves, and a female and male postabdomen with long basal spines (compare with Alonso, 1996). A. moniezi differs from A. elegans in a shorter and more convex labral keel, short antennules and female postabdomen with relatively deeper preanal corner (reaching more dorsal than postanal margin) and seta of basal segment of antennal exopodite is not reaching the end of the second segment (in $A$. elegans it reaches beyond). Postabdomen in several females, which correspond in all other characters to the rest of the population, is more like $C$. rectangula (former $A$. rectangula), as in Figure $7 \mathrm{C}-$ it does not resemble the postabdomen of $A$. elegans, which has a weakly expressed anal corner and anal margin not concave $-A$. moniez $i$ has a clearly demarked anal margin (demarcation of anal and postanal margin obvious, anal margin not strongly concave) as opposed to $C$. rectangula (postabdomen shorter, with strongly concave anal margin) and A. elegans (almost smooth continuation of anal and postanal margin, demarcation not obvious, margin not concave but nearly straight). The same shape of postabdomen was found in specimens from Balme d'Épy, Jura, France (Fig. 8). The clusters on the posteroventral corner of the valves (though not always clear) in $A$. moniezi seem to cluster more, not continuous as in A. elegans. On first limb, the IDL armature is long in $A$. moniezi, and no remnant of a third seta is visible, in A. elegans IDL armature consists of relatively shorter setules. Other limbs of A. moniezi could not be compared in detail with $A$. elegans based on the types (for a complete study, topotypical material would be necessary), but limbs of specimens from Balme d'Épy further corresponded to those of A. elegans. The male, for what could be seen from Richard's material of $A$. moniezi, is identical to that of A. elegans.

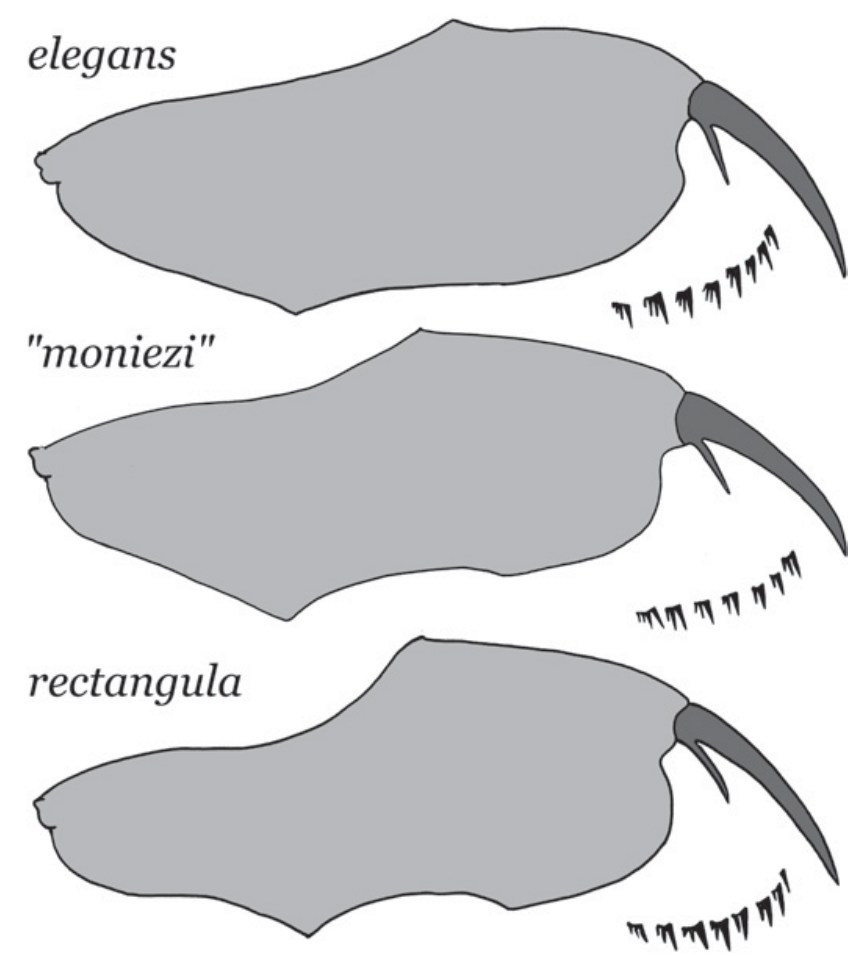

Fig. 8. Comparison of postabdomen shapes and marginal denticles (right) of "Alona" elegans, the moniezi-form and Coronatella rectangula. The "moniezi" postabdomen in the middle, has an intermediate shape between the two species, clearest in the concavity of the anal margin and expression of the preanal corner, and may be a hybrid. Drawings based on sympatric specimens from a single sample (Cave at Balme d'Épy, Franche-Comté, France).

\section{Distribution and biology}

Alona moniezi is only known from the area near Vichy, Auvergne, France and we present a second record of this form from Franche-Comté, France. A. elegans is widespread but rare in Western Europe (Flößner, 2000; Van Damme and Dumont, 2008b). Nothing is known about the biology of $A$. moniezi, found in a "turbid pool" at Vernet Castle (Richard, 1888). Inside infiltrating cave water in Franch-Comté, sympatric with Coronatella rectangula. For A. elegans, temporary pools are typical (Flößner, 2000).

\section{Note}

Hudec (2010) recently described a new species, lumped into Alona, A. montana Hudec, 2010, considered an endemic of the Tatrá Mountains in Slovenia. The author notes similarities with $A$. rectangula and $A$. elegans, the latter being the closest to Hudec's taxon. A. montana seems close to Richard's $A$. moniezi. To us, it shows that within the Coronatella branch, to which the "Alona" elegans complex belongs, the amount of variability and therefore the delineation of species remains poorly understood and new taxa still emerge. 


\section{Discussion}

\section{Notes on relationships}

The taxa considered here belong to three different species groups, currently residing in Alona sensu lato. Each of these groups may be assigned to a separate genus in the future after final revision of Alona (Van Damme and Dumont, 2008a, 2008b) and their current housing in Alona is temporary.

Alona karelica belongs to the Alona pulchella-complex, a widespread group in the southern hemisphere with over 15 species. All have a general Alona body shape and a postabdomen with straight parallel dorsal and ventral margins. Limbs of the A. pulchella-group are closest to new genera Maraura and Ovalona (Sinev and Shiel, 2008; Van Damme and Dumont, 2008b). Future position of the A. pulchella-group is closer to either of these genera than to Alona sensu stricto. Within the A. pulchella-complex, a small basal spine on the terminal claw of the postabdomen separates $A$. karelica; only $A$. bromelicola from Nicaragua shares this feature. Affinities between both were mentioned earlier (Smirnov, 1988; Sinev, 2002a). A. bromelicola is very close to $A$. karelica, but remains a separate species with peculiar characters. For example, A. bromelicola has very short aesthetascs on the first antenna and shorter spines on the second antenna (Sinev, 2002a). Limb characters are nearly identical, only differing in details (length of seta six in exopodite P3). A. karelica and $A$. bromelicola could be considered as morphologically close relatives. Although we did not investigate limbs in detail, populations from northern Neotropics of $A$. cf. karelica (e.g., in Rey and Vásquez (1986) and Mexican specimens studied here) share close affinities with $A$. karelica. Comparing postabdomen, differences can be noted (basal spine and distal marginal teeth are longer in Neotropical specimens), but variability of the European specimens is insufficiently known for a full species separation. Variation in characters of the Palaearctic populations of A. karelica was noted before by $\operatorname{Hudec}(1980,1986)$; Herbst (1974) shows larger distal marginal teeth in A. karelica from Germany. We attribute the Neotropical populations studied here to A. cf. karelica, yet we cannot exclude the possibility that this may later be considered as separate (sub-) species. The subtle morphological differences allow us to have a better understanding of the distribution of $A$. karelica, which is restricted to northwestern Palaearctic. To conclude, within the A. pulchellagroup, we can recognize a small and peculiar $A$. karelicacomplex, including $A$. karelica (NW-Palaearctic), $A$. cf. karelica (Mexico and Venezuela) and $A$. bromelicola (Nicaragua). The complex has a peculiar disjunction (Fig. 9), between the Palaearctic and the Neotropics.

Alona weltneri has all characters of the A. costatacomplex. Latter belongs to a section of Alona sensu lato called the Hexalona-branch (Van Damme and Dumont, 2008b), with six limbs, setulated labral keel and other features. We confirm that A. weltneri is not a name based on an aberrant specimen, but a valid species related to
A. costata. Transverse lateral head pores are typical for the A. costata-complex and these structures are accompanied in most species by underlying "sacks". A. weltneri takes in a relatively isolated position within the $A$. costata-group in two characters: (i) absence of sacks beneath the lateral pores, (ii) no protruding dorsodistal margin on the postabdomen. Additionally, lateral pores have a thick chitineous ring and males lack a projection for the gonopores in $A$. weltneri. In limb characters, as far as we could study, $A$. weltneri is identical to $A$. costata. Exopodite setae lengths of P3 and P4 are the same and only length of ODL seta seems shorter in A. weltneri. The differences seem predominantly present in head pores, postabdomen and shape and armature of labral keel. We noted such a speciation in chydorids earlier, where limb characters remain nearly identical, but "external" characters diverge, in the Phreatalona protzi-complex (former Alona protzi-complex) between $P$. protzi and $P$. phreatica (see Van Damme et al., 2009). These differences may have resulted from a sympatric speciation or isolation of populations followed by morphological divergence. A former geographical isolation seems less likely, unless it dates far back and was severe: all A. costata forms worldwide, even endemics in isolated regions (e.g., Drakensberg in South Africa; Sinev, 2008) are externally more similar to Palaearctic A. costata than A. weltneri! The latter habitus and postabdomen clearly diverge from A. costata. Isolation of $A$. weltneri from the ancestral stock must have been sufficiently strong to lead to a different morphotype in postabdomen and head pores, but did not lead to success type: $A$. weltneri is virtually absent in surface waters when compared to its sibling $A$. costata. As discussed below for $A$. karelica, A. weltneri may be restricted to a yet unknown biotope, and such an isolation may have allowed divergence in morphology.

Finally, A. moniezi belongs to the A. elegans complex, a group to be removed from Alona. The A. elegans group is closer to Coronatella than to Alona and may need allocation to this genus (Van Damme and Dumont, 2008b, 2010), so at present the situation seems confusing. A. moniezi shows similarities with Coronatella rectangula (former Alona rectangula) and both "A." elegans and $C$. rectangula were considered as very closely related before (Smirnov, 1971). Our investigation of " $A$." moniezi shows that male morphology, female striation and armature of P1 correspond closer to "Alona" elegans, not with Coronatella rectangula. However, the postabdomen of several females of "A." moniezi (Fig. 7C) resembles $C$. rectangula more than that of " $A$." elegans and seems to falls beyond variability of true " $A$." elegans populations we studied (e.g., from Sicily). There are a few small differences from "A." elegans (see under differential diagnosis), like a round short labrum and a more concave anal margin, reminding of $C$. rectangula.

"Alona" moniezi females may seem morphological hybrids of elegans $\times$ rectangula. Dumont et al. (1979) suggested such a natural hybrid, females with elegans body but rectangula-like postabdomen from Tunisia (illustrations in Dumont et al., 1979: 265, Fig. 4). 


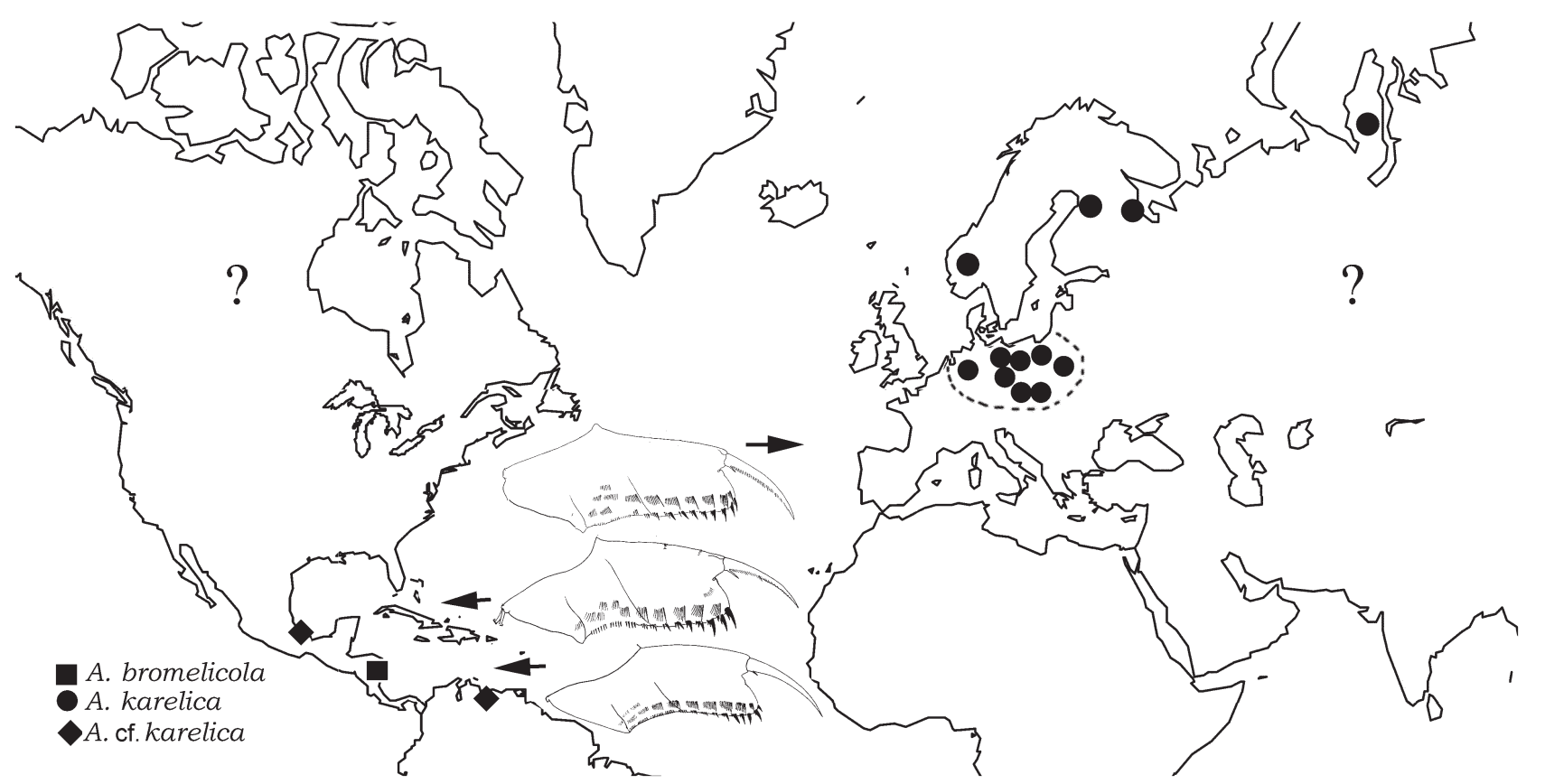

Fig. 9. Records of Alona karelica Stenroos, 1897, A. cf. karelica and A. bromelicola Smirnov, 1988 show a strong disjunction in this small complex. Relatively more records of $A$. karelica exist from Western Europe, just south of the Baltic Sea (former Pomerania). From most of the Holarctic, close siblings have not been reported, but large areas may be poorly sampled for these chydorids (question marks). In Neotropics, A. cf. karelica shows small differences in morphology (Mexico, Venezuela) as shown for the postabdomen (upper: A. karelica Palaearctic, middle A. cf. karelica Neotropics, below A. bromelicola). Map compiled from Smirnov (1971), Flößner (2000) and additional records mentioned here under Distribution $A$. karelica.

We checked the original samples from Tunisia; males of A. elegans occurred in this locality together with abundant $C$. rectangula females, true $A$. elegans females and the intermediate form. Besides "A." moniezi and the Tunisian record, we have third observation of such an intermediate form, the population from a cave in Franche-Comté, France. In the latter locality, female "A." elegans with C. rectangula-like postabdomen again coexisted with abundant females of $C$. rectangula. No other chydorids were found in the sample. The intermediate postabdomen shape is shown in Figure 8 in comparison to the latter two species, on specimens from the latter locality. This is clearly not elegans nor rectangula, seems almost intermediate, but the morphology of the females further corresponds largely to "A." elegans. It is impossible to be certain of hybridization here based on phenotypes, but latter records may hypothetically be among the few natural occurrences of chydorid hybridization as Dumont et al. (1979) suggested. Frey (1986) gives a review on hybridization in Chydoridae and Eurycercidae under laboratory conditions, but reports of occurrences in nature of hybrids are rare. Although no studies have ever been performed, it could be speculated that genetic barriers between male elegans and female rectangula might be insufficient to keep these from intraspecific hybridization. Male postabdomens are phenotypically quite similar between rectangula and elegans in shape, yet size of both species differs, so crossing may not be straightforward. Hypothetically, if both would occur in small (temporary) waterbodies, large population sizes and a simultaneous occurrence of a large proportion of males might enhance possibilities of species crossing if males are unspecific. Experiments would allow a possibility to investigate hybridization in Coronatella rectangula and other species. However, the similarities between postabdomens of A. moniezi and Coronatella rectangula, given the phenotypic plasticity of the elegans-group and Coronatella rectangula, may not be a strong enough argument for the possibility of hybridization between these two species. Other intermediate characters should be investigated and variability of A. elegans studied in more detail, to test the hypothesis.

Coronatella shows a considerable phenotypical plasticity resulting in taxonomical confusion, also typical for C. rectangula in Europe (and C. anemae, Van Damme and Dumont, 2008b). Such complex situation may also be a sign of introgression, as in Daphnia (O.F. Müller, 1785). A revision of $A$. elegans based on material from terra typica (Bohemia, Czech Republic), will allow a better delineation of this group. With an apparently small radiation in Spain (A. orellanai and A. salina, see map in Van Damme and Dumont, 2008b), diversity and phenotypical variability of the complex are poorly studied. The "Alona" elegans-group needs taxonomic revision, including topotypical material. As in Spain, several (sub-) species may still be present under this complex even in Europe (there are currently two A. elegans subspecies of which the status needs revision, A. elegans herbsti Smirnov, 2001, former A. elegans arcuata Herbst, 1964, and A. elegans lebes Dumont and Van De Velde, 1975). Recently two new species were described from SE-Russia and Mongolia 
(A. floessneri and A. irinae; Sinev et al., 2009). The current "Alona" moniezi, illustrates the difficulties in elegans and rectangula-like forms, which belong to the Coronatellabranch. We did not shift "Alona" moniezi in this paper, which clearly does not belong to Alona sensu stricto (in its narrowest sense, the $A$. quadrangularis-group), to the genus Coronatella. Such an action will depend on revision and allocation of the complete "A." elegans-group, hitherto unrevised. The above also illustrates that for all these rectangula-like forms, we are at an upper limit of our understanding based on morphology - molecular methods are necessary to unravel the extent of cryptic diversity in both the rectangula- and elegans-groups of the Coronatella branch in the Chydoridae, perhaps more than for any other Alona-like taxa.

\section{Rarity in the Palaearctic}

Why are these three taxa so rare in the Palaearctic - is it an artifact due to limited knowledge, or a natural phenomenon? Firstly, poor original descriptions of these species did not allow quick identification, so it may be partly an artifact. Few specialists in the world would be able to recognize $A$. karelica and $A$. weltneri today. Furthermore, $A$. weltneri and $A$. costata are very hard to tell apart and even more cryptic species within this complex could be present in Europe. With A. costata so widely distributed and common in the Palaearctic, its sibling may be easily overlooked and distribution of $A$. weltneri may therefore be wider than currently assumed. Confusion with A. guttata may complicate the situation (see Soesbergen and van de Sande, 2009). However, quality of descriptions can not be the only reason, as these animals do not only appear scarce in records but also in absolute number.

An overlooked habitat and patchiness may be additional reasons for finding such chydorids in low numbers. Once a peculiar niche is identified, aimed "hunting" reveals large populations. We found this method to be successful earlier, in finding large populations of the riverine Phreatalona protzi (Hartwig, 1900) and the hydra predator Anchistropus emarginatus Sars, 1862 (Van Damme and Dumont, 2007; Van Damme et al., 2009).

A peculiar ecology is likely for $A$. karelica. The species is closest to A. bromelicola, only found in water of epiphytic bromeliads (Smirnov, 1988). Although no such morphological specializations are apparent in A. karelica, the overall similarities in morphology may indicate occupation of a similar microenvironment. Virtual absence of A. karelica in littoral samples may reflect the fact that this is not its true habitat. Instead, we think it may be associated with moss. Its close relative $A$. bromelicola is semi-terrestrial and $A$. karelica has been reported twice in association with Sphagnum stands (Flößner, 2000; Kuczyńska-Kippen, 2008). It could well be an epibiont of these bryophytes, or very closely associated, like $A$. rustica. It may be no coincidence that distribution of $A$. karelica in Europe (Fig. 9) coincides with regions of high Sphagnum diversity ( $>36$ species of Sphagnum; compare Fig. 9 with map in Séneca and Söderstrom, 2008: 127). Marginal biotopes like semi-terrestrial microhabitats, e.g., mosses or other waterfilled cavities in terrestrial plants, are easily overlooked in classic zooplankton sampling. In tropics, mosses have been shown to reveal bryophilic Cladocera, e.g., Bryospilus (see Frey, 1980). Because of this, the co-occurrence of $A$. cf. karelica with Bryospilus repens in the Coatzacoalcos river (Mexico) could result from washing out.

For A. weltneri, ecological preference is unknown. Wider sampling of a particular microhabitat, once known, may reveal larger populations and a relatively wider distribution than currently assumed.

As Europe is the most intensively studied region for Cladocera, scarcity of A. karelica, A. weltneri and A. elegans, may not be attributed to ecology alone. Decline of these species, or their habitats in Europe, may also be realistic. These populations may be Pleistocene relicts, which were more common when conditions for their survival were more favorable than in the current interglacial.

For example, A. karelica is the only member of the A. pulchella-group in Europe north of the Mediterranean. The $A$. pulchella-group is otherwise widespread and common in other regions of the world, yet most species seem intolerant to the climate conditions of northern latitudes. Distributions of two common species from this group, A. pulchella (Australia, South East Asia) and A. cambouei (Africa, Mediterranean, Tropical Asia from Palestine to China), do not seem to reach latitudes above $40^{\circ} \mathrm{N}$. Apart from three representatives in temperate Holarctic zone with atypical postabdomen for the group (A. setulosa Megard, 1967 and likely A. lapidicola Chengalath and Hann, 1981 and A. borealis Chengalath and Hann, 1981) and representatives that withstand conditions at the high altitudes in the Andes $(A$. nigra Smirnov, 1996 and A. altiplana Kotov, Sinev and Berrios, 2010 and even A. glabra Sars, 1901) (Kotov et al., 2010), distribution of the Alona pulchella-complex suggests the majority of species to prefer warm climates or even physiologically restricted to such conditions (stenotherms). The group harbors some of the most common Aloninae found in littoral of lakes and temporary pools in the southern hemisphere, mainly in tropical and arid regions (e.g., A. glabra Sars, 1901, A. cambouei de Guerne and Richard, 1893 and A. pulchella King, 1853). The widespread $A$. cambouei occurs, commonly, in temporary waterbodies or lake littoral in warmer regions and is a dominant chydorid in arid lowlands of Arabia, Africa and the Mediterranean (Van Damme, pers. obs.); A. pulchella, vicariant of $A$. cambouei, has a similar ecology in large parts of South East Asia and Australia. A. karelica derived from this group of warmth-loving stenotherms and is the only extant cold-tolerant representative in the Palaearctic. Having its closest relative(s) in the Neotropics (Fig. 9), A. karelica may be a true relict of warmer periods and/or a specially adapted cold-tolerant lineage. From this viewpoint, within its group, it is likely a relict, pushed back 
into a marginal biotope. Large zones where this species now occurs were glaciated during the last Ice Ages (like N-Poland, e.g. see Liszkowski, 1987), suggesting northern post-glacial expansion. Where and in which habitats populations of $A$. karelica survived the glacial maxima, is unclear. In-depth discussion on glacial refugia in the Palaearctic has yet to start for Chydoridae, yet taxa occurring in former glaciated areas logically entered from glacial refugia into newly formed habitats. A virtually vegetationless semi-arid environment covered most of non-glaciated Europe during the Last Glacial Maximum (e.g., Adams and Faure, 1997). So, either A. karelica was already present in such a warmer semi-arid environment, which is typical for its warmth-loving relatives (like A. cambouei), and later underwent a habitat shift, or survived glacial maxima in refugia. Few such refugia were suggested for Sphagnum species in Europe like the Atlantic coast (France, UK and Spain) and SE-Poland (Gajewski et al., 2001; Szövényi et al., 2006). If indeed linked to Sphagnum stands as circumstantial evidence suggests, such refuges may have been possible for $A$. karelica (however unrecorded from Spain or France). Brehm used A. karelica as example of a "Selesian" glacial relic (Thienemann, 1950), a species that survived in southern Poland during the ice ages. Close to the animal's main distribution area and terra typica, it seems a valid region for a glacial refuge.

A disjunction between Neotropics and Palaearctic of the small A. karelica-complex seems peculiar (Fig. 8). Absence in the Nearctic (extinction or undersampling?) of a close sibling of $A$. karelica, is more surprising than presence of $A$. cf. karelica in the Neotropics. The latter, for example the largest part of Mexico, is becoming an increasingly well-known region for Cladocera. Surprisingly, and in contrast, North America is now lagging behind in continuation of morphological-taxonomical efforts in Cladocera. Training of experts in this region since Frey and his students is virtually absent, although molecular studies confirm that cryptic diversity is high and much remains to be discovered in the vast Nearctic. Although the Mexican specimens studied here may not be identical to the European, they are nevertheless closest to A. karelica. Presence or former presence of $A$. cf. karelica or a sibling in the Nearctic would make sense from a biogeographical point of view, but no evidence has yet been collected. Information on $A$. weltneri is too scarce and a peculiar niche is possible as well.

The third taxon, "A." moniezi, seems restricted to isolated populations in France. Males (types) clearly belong to A. elegans. A. elegans is also rare in Western Europe, but when present, populations occur in considerable larger numbers than $A$. weltneri or A. karelica. In general, the distribution pattern of species of the A. elegans-complex suggests a relict group, as seen by its large disjunctions, illustrated for example by two species in the Far East related to A. salina (A. irinae and A. floessneri; Sinev et al., 2009) and its absence in most of the African continent (Van Damme and Dumont, 2008b). Taxa of the elegans-group prefer temporary waters (e.g., Alonso, 1996; Van Damme and Dumont, 2008b), habitats more common in currently arid and/or large leveled uninhabited regions, scarce in vegetation. Apparent scarcity of A. elegans could be a combination of an ecological preference for larger temporary pools and decline of these habitats (due to a natural phenomenon and human-mediated factors like land use) in Europe. Also other branchiopods typical for temporary pools, disappear in Western Europe because of habitat loss. For example, Belgium has no Notostraca and virtually no "Conchostraca" left, although these were present even just a century ago (Brendonck, 1989). Undersampling may add to its rarity; for example, the A. elegans complex has not been confirmed from the New World yet is present in extreme south and east of the Old World (Van Damme and Dumont, 2008b; Sinev et al., 2009). Finally, climatic conditions may be an additional factor. The A. elegans complex is not recorded before from France, it is possible that populations are very rare and actually disappearing, remnants of a more arid climate phases of the past; undersampling of a suitable habitat cannot be excluded as a reason. In addition, in the hypothetical case that $C$. rectangula and "Alona" elegans would indeed hybridize, the latter could be even under pressure of disappearing in Europe through introgression...

The fact remains that A. karelica, A. weltneri and " $A$." elegans are currently among the rarest Alona-like species in Europe. In comparison to species like A. affinis, A. quadrangularis, A. costata or A. guttata, populations can be considered extremely rare. Aimed sampling a wider spectrum of (micro) habitats, such as temporary pools or Sphagnum mats in the Holarctic, may reveal more, yet several other factors may cause their decline. Because of their rarity, few localities certain to harbor populations of A. karelica, A. weltneri and "A." elegans in Europe, may be important. Until wider occurrence is known, these species could be considered as vulnerable in the region. Localities may be also significant for protection of other microinvertebrates; for example, Kuczyńska-Kippen (2008) notes very rare species of rotifers in association with A. karelica from Poland, indicating an important habitat. The latter area in Poland (W-Pomerania) seems the only one where both $A$. karelica and $A$. weltneri were reported. The present study may help future recognition of these rare animals in zooplankton samples and hopefully a better view on their distribution and ecology.

\section{Conclusions}

We confirm $A$. weltneri and A. karelica as valid species, respectively from the $A$. costata- and $A$. pulchellacomplexes. "Alona" moniezi is a peculiar form: males are identical to "A." elegans and females seem a mixture of "A." elegans and Coronatella rectangula. Postabdomen of several A. moniezi females show similarity with Coronatella rectangula and may indicate hybridization. We include three records of such an intermediate morphology, in two occasions sympatric with $C$. rectangula. It forms an argument for positioning the $A$. elegans-group within Coronatella, yet revision of the group is necessary. 
Limbs confirm $A$. karelica as member of the $A$. pulchella group. It seems closely related to the Neotropical bromeliad-inhabiting $A$. bromelicola. A population from Mexico is here regarded as A. cf. karelica, indicating a peculiar disjunction in distribution of this complex and possible cryptic speciation. A. weltneri appears nearly identical in limb characters to $A$. costata but postabdomen and head pores show significant morphological divergence of this species.

Apparent scarcity in the Palaearctic of A. karelica, A. weltneri and "A." elegans may result from rarity of their (poorly known) habitats, and a possible relict nature for these taxa in Europe. The picture may be partly incomplete due to undersampling and poor recognition. We suggest $A$. karelica may have a closely plant-associated mode of life (in moss), similar to that of A. bromelicola.

Acknowledgements. The authors wish to thank Dr Igor Hudec, Dr Charles Oliver Coleman, Dr Dietrich Flößner, Dr T. Chad Walter, Dr Frank D. Ferrari and Miss Noemí Dimas-Flores for loaning the specimens this paper was based on, and to A.Y. Sinev and a second anonymous referee for comments.

\section{References}

Adams J.M. and Faure H., 1997 (eds.). QEN members. Review and Atlas of Palaeovegetation: Preliminary land ecosystem maps of the world since the Last Glacial Maximum, Oak Ridge National Laboratory, TN, http://www.esd.ornl.gov/ projects/qen/adams1.html

Alonso M., 1996. Crustacea, Branchiopoda. In: Fauna Ibérica, vol. 7, Ramos M.A. et al. (eds.), Museo Nacional de Ciencias Naturales, CSIC, Madrid.

Belyaeva M. and Taylor D., 2009. Cryptic species within the Chydorus sphaericus species complex (Crustacea: Cladocera) revealed by molecular markers and sexual stage morphology. Mol. Phyl. Evol., 50, 534-546.

Brendonck L., 1989. A review of the phyllopods (Crustacea: Anostraca, Notostraca, Conchostraca) of the Belgian fauna. In: Wouters K. and Baert L. (eds.), Invertebraten van België [Invertébrés de Belgique], Proceedings of the Symposium "Invertebrates of Belgium", Brussels, 25-26 Nov. 1988, Royal Belgian Institute of Natural Sciences, Brussels, 129135.

Dimas-Flores N., 2002. Contribución al conocimiento de la comunidad de los órdenes Anomopoda y Ctenopoda de la cuenca baja del Río Coatzacoalcos. Unpublished Bachelor Thesis, Universidad Nacional Autónoma de México (available online at http://bidi.unam.mx/).

Dodson S.I. and Frey D.G., 1991. Cladocera and other Branchiopoda. In: Thorp J.H. and Covich A.P. (eds.), Ecology and Classification of North American Freshwater Invertebrates, Academic Press, Inc., 723-786.

Dole-Olivier M.-J., 1998. Surface water-groundwater exchanges in three dimensions on a backwater of the Rhône River. Freshw. Biol., 40, 93-109.

Dumont H.J., Laureys P. and Pensaert J., 1979. Anostraca, Conchostraca and Copepoda from Tunisia. Hydrobiologia, 66, 259-274.
Elías-Gutiérrez M., Suárez-Morales E., Gutiérrez-Aguirre M., Silva-Briano M., Granados-Ramírez J.G. and GarfiasEspejo T., 2008. Guía ilustrada de los microcrustáceos (Cladocera y Copepoda) de aguas continentales de México, ECOSUR, UNAM, CONABIO.

Flößner D., 1962. Zur Cladocerenfauna des Stechlinsee-Gebietes I. Über Morphologie und Variabilität einiger Formen und über Funde seltener Arten. Limnologica (Berlin), 1, 217-229.

Flößner D., 2000. Die Haplopoda und Cladocera (ohne Bosminidae) Mitteleuropas, Backhuys Publishers, Leiden.

Frey D.G., 1980. The non-swimming chydorid Cladocera of wet forests, with descriptions of a new genus and two new species. Int. Rev. Gesamt. Hydrobiol., 65, 613-641.

Frey D.G., 1986. The non-cosmopolitanism of the chydorid Cladocera: implications for biogeography and evolution. In: Gore R.H. and Heck K.L. (eds.), Crustacean Biogeography, Balkema, Rotterdam, 237-256.

Fryer G.O., 1993. The freshwater Crustacea of Yorkshire. A faunistic \& ecological survey, Yorkshire Naturalists' Union \& Leeds Philosophical and Literary Society, Titus Wilson and Son, Kendal.

Gajewski K., Viau A., Sawada M., Atkinson D. and Wilson S., 2001. Sphagnum peatland distribution in North America and Eurasia during the past 21000 years. Global Biogeochem. Cycles, 15, 297-310.

Herbst H.V., 1962. Blattfüsskrebse (Phyllopoden: Echte Blattfüsser und Wasserflöhe), Kosmos, Stuttgart.

Herbst H.V., 1974. Zwei seltene Chydoridae (Cladocera) am Niederrhein. Gew. Abw., 53/54, 133-137.

Herr O., 1917. Die Phyllopodenfaunader preußischen Oberlausitz und der benachbarten Gebiete. Abh. Naturf. Ges. Görlitz, 28, 1-162.

Hudec I., 1980. Alona karelica Stenroos 1897 (Crustacea, Cladocera) z východného Slovenska. Faunistické Správy, Biológia (Bratislava), 35, 607-608.

Hudec I., 1986. Further notes on Alona karelica (Cladocera, Chydoridae) from East Slovakia. Věst. čs. Společ. zool., 50, 188-191.

Hudec I., 2010. Fauna Slovenska III. Anomopoda, Ctenopoda, Haplopoda, Onychopoda (Crustacea: Branchiopoda), VEDA, Vydavatel stvo Slovenskej adadémie vied, Bratislava.

Idris B.A.G. and Fernando C.H., 1981. Cladocera of Malaysia and Singapore with new records, redescriptions and remarks on some species. Hydrobiologia, 77, 233-256.

Keilhack L., 1905. Zur Cladocerenfauna des Madüsees in Pommern. Beitrage zur Fauna des Madüsees in Pommern. Von Dr. M. Samter und Dr. W. Weltner. Erste Mitteilung. Arch.f. Naturg., 71, 138-162.

Keilhack L., 1908. Zür Cladocerenfauna der Mark Brandenburg. Mitt. Zool. Mus. Berlin, III, 4, 435-488.

Kotov A.A. and Ferrari F., 2010. The taxonomic research of Jules Richard on Cladocera (Crustacea: Branchiopoda) and his collection at the National Museum of Natural History, U.S.A. Zootaxa, 2551, 37-64.

Kotov A.A., Sinev A.Y. and Berrios V.L., 2010. The Cladocera (Crustacea: Branchiopoda) of six high altitude water bodies in the North Chilean Andes, with discussion of Andean endemism. Zootaxa, 2430, 1-66.

Kuczyńska-Kippen N., 2008. Spatial distribution of zooplankton communities between the Sphagnum mat and open water in a dystrophic lake. Pol. J. Ecol., 56, 57-64. 
Liszkowski J., 1987. Zonal arrangement of thermal regimes of Pleistocene ice sheets as indicated by field data from Poland, The Physical Basis of Ice Sheet Modelling (Proceedings of the Vancouver Symposium, August 1987), IAHS Publ., n ${ }^{\circ} 170$.

Maiphae S., Pholpunthin P. and Dumont H.J., 2005. Species richness of the Cladocera (Branchiopoda: Anomopoda and Ctenopoda) in southern Thailand, and its complementarity with neighboring regions. Hydrobiologia, 537, 147-156.

Rey J. and Vásquez E., 1986. Cladocères de quelques corps d'eaux du bassin moyen de l'Orénoque (Vénézuéla). Ann. Limnol., 22, 137-168.

Richard J., 1888. Entomostracés nouveaux ou peu connus. Bull. Soc. Zool. Fr., 13, 1-6.

Scourfield D.J., 1907. An Alona and a Pleuroxus new to Britain (A. weltneri Keilhack and P. denticulatus Birge). J. Quekett Micr. Club, 10, 71-76.

Séneca A. and Söderström L., 2008. Species richness and distribution ranges of European Sphagnum. Fol. Crypt. Est., 44, 125-130.

Sinev A.Y., 1999. Alona costata Sars, 1862 versus related palaeotropical species: the first example of close relations between species with a different number of main head pores among Chydoridae (Crustacea: Anomopoda). Arthropoda Selecta, 8, 131-148.

Sinev A.Y., 2002a. Place of a Central American bromeliadinhabiting cladoceran Alona bromelicola Smirnov, 1988 within the genus (Chydoridae, Anomopoda, Branchiopoda). Arthropoda Selecta, 11, 109-116.

Sinev A.Y., 2002b. A key to identifying cladocerans of the genus Alona (Anomopoda, Chydoridae) from the Russian European part and Siberia. Zoologicheskiy Zhurnal, 81, 926-939 [in Russian].

Sinev A.Y., 2008. A new species related to Alona costata Sars, 1862 (Cladocera: Anomopoda: Chydoridae) from South Africa. Zootaxa, 1707, 23-36.

Sinev A.Y. and Shiel R.J., 2008. Redescription of Alona macracantha Smirnov and Timms, 1983 and its assignment to Maraura gen. nov. (Cladocera: Anomopoda: Chydoridae). J. Nat. Hist., 42, 2809-2824.

Sinev A.Y., Alonso M. and Sheveleva N.G., 2009. New species of Alona from South-East Russia and Mongolia related to Alona salina Alonso, 1996 (Cladocera: Anomopoda: Chydoridae). Zootaxa, 2326, 1-23.

Smirnov N.N., 1963. On inshore Cladocera of the Volga Water Reservoirs. Hydrobiologia, 21, 166-176.

Smirnov N.N., 1971. Chydoridae fauny mira-Fauna USSR. Rakoobraznie, 1(2), Leningrad [English translation: Chydoridae of the world. Israel Program for Scientific Translations, Jerusalem, 1974].
Smirnov N.N., 1988. Cladocera (Crustacea) from Nicaragua. Hydrobiologia, 160, 63-77.

Soesbergen M., 2002. Naamlijst van de Nederlandse Kieuwpootkreeften (Branchiopoda). Nederlandse Faunistische Mededelingen, 16, 25-38.

Soesbergen M. and van de Sande J., 2009. Aanvullingen op de naamlijst van de Nederlandse Kieuwpootkreeften (Crustacea: Branchiopoda). Nederlandse Faunistische Mededelingen, 30, 75-82.

Stenroos K.E., 1897. Zur Kenntnis der Crustaceen-Fauna von Russisch-Karelien. Acta Soc. Fauna Fl. Fenn., 15, 1-72.

Szövényi P., Hock Z., Urmi E. and Schneller J., 2006. Contrasting phylogeographic patterns in Sphagnum fimbriatum and Sphagnum squarrosum (Bryophyta, Sphagnopsida) in Europe. New Phytol., 172, 784-794.

Thienemann A., 1950. Verbreitungsgeschichte der Süsswassertierwelt Europas. Die Binnengewässer, Band XVII, Thienemann A. and Stuttgart E. (eds.), Schweizerbartsche Verlagsbuchhandlung, Stuttgart.

Van Damme K. and Dumont H.J., 2007. Limb morphology of the carnivorous anomopods Anchistropus emarginatus Sars, 1862 and Pseudochydorus globosus (Baird, 1843) (Crustacea: Branchiopoda: Anomopoda). Ann. Limnol. - Int. J. Lim., 43, 271-284.

Van Damme K. and Dumont H.J., 2008a. The 'true' genus Alona Baird, 1843 (Crustacea: Cladocera: Anomopoda): characters of the A. quadrangularis-group and description of a new species from Democratic Republic Congo. Zootaxa, 1945, $1-25$.

Van Damme K. and Dumont H.J., 2008b. Further division of Alona Baird, 1843: separation and position of Coronatella Dybowski and Grochowski and Ovalona gen.n. (Crustacea: Cladocera). Zootaxa, 1960, 1-44.

Van Damme K., Brancelj A. and Dumont H.J., 2009. Adaptations to the hyporheic in Aloninae (Crustacea: Cladocera): allocation of Alona protzi Hartwig, 1900 and related species to Phreatalona gen. nov. Hydrobiologia, 618, $1-34$.

Van Damme K., Kotov A.A. and Dumont H.J., 2010. A checklist of names in Alona Baird 1843 (Crustacea: Cladocera: Chydoridae) and their current status: an analysis of the taxonomy of a lump genus. Zootaxa, 2330, 1-63.

Weigold H., 1911. Biologische Studien an Lyncodaphniden und Chydoriden. Int. Rev. Ges. Hydrobiol., Biol. Suppl., 3, $1-118$.

Yalim F.B. and Ciplak B., 2005. A representative of the pulchella group in Anatolia: Alona cambouei Guerne and Richard, 1895 (Cladocera: Chydoridae). Turk. J. Zool., 29, 61-65. 